IZA DP No. 7181

Is the Persistent Gender Gap in Income and Wages Due to Unequal Family Responsibilities?

Nikolay Angelov

Per Johansson

Erica Lindahl

January 2013 


\title{
Is the Persistent Gender Gap in Income and Wages Due to Unequal Family Responsibilities?
}

\author{
Nikolay Angelov \\ IFAU and UCLS \\ Per Johansson \\ IFAU, Uppsala University and IZA \\ Erica Lindahl \\ IFAU \\ Discussion Paper No. 7181 \\ January 2013 \\ IZA \\ P.O. Box 7240 \\ 53072 Bonn \\ Germany \\ Phone: +49-228-3894-0 \\ Fax: +49-228-3894-180 \\ E-mail: iza@iza.org
}

\begin{abstract}
Any opinions expressed here are those of the author(s) and not those of IZA. Research published in this series may include views on policy, but the institute itself takes no institutional policy positions. The IZA research network is committed to the IZA Guiding Principles of Research Integrity.

The Institute for the Study of Labor (IZA) in Bonn is a local and virtual international research center and a place of communication between science, politics and business. IZA is an independent nonprofit organization supported by Deutsche Post Foundation. The center is associated with the University of Bonn and offers a stimulating research environment through its international network, workshops and conferences, data service, project support, research visits and doctoral program. IZA engages in (i) original and internationally competitive research in all fields of labor economics, (ii) development of policy concepts, and (iii) dissemination of research results and concepts to the interested public.
\end{abstract}

IZA Discussion Papers often represent preliminary work and are circulated to encourage discussion. Citation of such a paper should account for its provisional character. A revised version may be available directly from the author. 


\section{ABSTRACT}

\section{Is the Persistent Gender Gap in Income and Wages Due to Unequal Family Responsibilities?*}

We compare the income and wage trajectories of women in relation to their male partners before and after parenthood. Focusing on the within-couple gap allows us to control for both observed and unobserved attributes of the spouse and to estimate both short- and long-term effects of entering parenthood. Our main finding is that 15 years after the first child was born, the male-female gender gaps in income and wages have increased with 35 and 10 percentage points, respectively. In line with a collective labor supply model, the magnitude of these effects depends on relative incomes or wages within the family.

JEL Classification: J21, D13, C21

Keywords: gender gap, quantile regression, income, wages

Corresponding author:

Per Johansson

IFAU

Box 513

SE-75120 Uppsala

Sweden

E-mail: per.johansson@ifau.uu.se

\footnotetext{
* We are grateful for comments from Daniel Avdic, Daniel Waldenström, Olof Åslund, and seminar participants at IFAU and the Department of Economics at the University of St. Gallen.
} 


\section{Introduction}

The gender gap in income and wages narrowed considerably during the 1970s in most industrialized countries in the world (Blue and Kahn, 2000). Reasonable explanations for the narrowing gender gap are higher educational attainment among women, less occupational gender-segregation and implementations of equal opportunity policies (see e.g. Goldin 1990; O’Neill and Polachek 1993; Blau and Kahn 1997; Blau 1998, Edin and Richardson, 2002). However, during the last 30 years the process of a narrowing gender gap has stagnated (Blau and Kahn, 2000). In Sweden, the gender gap has even started to widen again (SCB, 2009).

A suggested explanation for the stagnation of the gender gap is the unequal gender division of family responsibilities (e.g., Datta Gupta and Smith, 2002). Although women nowadays are well established on the labor market, they still do the lion part of the household work and the child care (see, e.g., Evertsson and Nermo, 2007, Tichenor, 1999 and Booth and van Ours, 2005). Furthermore, survey evidence shows that women's larger responsibility for household work emerges when couples have their first child. Before entering parenthood, household work is split more equally between the spouses. After the arrival of the first child women increase their share (Van der Lippe and Siegers, 1994; Gauthier and Furstenberg, 2002). Our interpretation of these results is that the arrival of the first child manifests and intensifies traditional gender roles which have implications for the evolution of the gender gap in earnings and wages.

The established empirical observation that women increase their already large share of household work when families receive their first child, in combination with the reasonable conjecture that this increase in home production is associated with relatively lower effort on the labor market, could explain both the initial decrease and the later stagnation of the gender gap in earnings observed during the last decades. If the increase in female labor supply in the 1960s and 1970s was primarily driven by women with no or little family responsibilities (and with higher productivity than the average male, cf., Heckman, 1978), this labor supply increase would show up in a decrease in the gender wage gap. However, with gradually increasing labor supply among women, by necessity, women with family 
responsibilities would eventually also enter the labor force. In Sweden, the increase in the female labor force participation during the late 1970s was, in particular, driven by women with pre-school children - see Figure 2.

The aim of this paper is to estimate short- and long-term effects of entering parenthood on the gender gap in income and wages. The focus is on women's income and wage trajectories in relation to their partners' income and wage trajectories before and after the arrival of the first child. In contrast to earlier studies, estimating the effect of parenthood, we use neither variation across women or men with and without children, nor variation in the timing of when a particular female or male enters parenthood (see e.g., Waldfogel, 1997; Buding and England, 2001; Kennerberg, 2007; Loughren and Zissimopolus, 2008, Sasser, 2008). Instead we explore the within-family variation over time. The basic identification assumption is that the decision of when to enter parenthood is not induced by unobservable information of a changed direction of the income and wage trajectory of one of the spouses. It should be noted that our approach does not allow us to estimate the effect of parenthood for men and women separately; instead we ask how the within-couple gender gaps in income and wages, respectively, are affected by becoming parent.

One advantage with this approach is that we are able to control for observed as well as unobserved attributes of the spouse, which is ignored in most studies aiming at estimating the effect of parenthood. Another advantage is that our framework allows us to directly study the importance of comparative advantages within the household. ${ }^{1}$ To this end, we use quantile regressions to study how any potential effect of parenthood differs across the distribution of the gender gap in income and wages in the absence of having a child. ${ }^{2}$

\footnotetext{
${ }^{1}$ We do not claim that the gender division of household work is solely determined by comparative advantages on the labor market. Recent studies by Boye (2008), Booth and van Ours (2005), Evertsson and Nermo (2007) and Tichenor (1999) present evidence that women do relatively more unpaid household work than men also when the incomes are more equally distributed within the household. Studies in gender theory explain this by the importance of gender norms (see e.g. West and Fenstermaker, 1995). Akerlof and Kranton (2000) instead stress the importance of gender identity. Nevertheless, our results clearly indicate that comparative advantages on the labor market play a very important role (see section 5.2).

${ }^{2}$ Within-household specialization is discussed in, e.g., Manser and Brown (1980), McElroy and Horney (1981), Chiappori (1991), and Konrad and Lommerud (1995).
} 
The empirical analysis is based on universal administrative Swedish registers. These data allow us to match mothers and fathers with each other and our unit of observation is parent couples. We are able to track parents' incomes and wages over a significant part of their labor market career, starting a few years before parenthood until about 15 years after the arrival of the first child.

Our main finding is that 15 years after the first child was born, the percentage difference between men's and women's incomes had increased by 35 percentage points compared to the pre-child difference. The corresponding number for wages is 10 percentage points. Using quantile regressions, we find that the effect of parenthood on the male-female gap increases with the income and wage gap the couple would have experienced in absence of parenthood. Thus, our results show that there has been a significantly higher cost of entering parenthood for women than for men. As the increase in female labor supply during the last decades has been particularly driven by women with children, the unequal division of the monetary cost of parenthood is one likely explanation for the stagnation of the gender gap. Finally, for the large majority of couples the effect of parenthood implies an increased gender gap in incomes and wages, but for the 20 percent of the couples with the smallest or with a negative counterfactual malefemale gap, the effect is negative. The general message of this analysis is that the match of the partner is crucial for the magnitude of the effect of parenthood on incomes and wages. Comparative advantages in terms of earnings potential are important for how the monetary costs of parenthood are shared between the parents.

The rest of the paper has the following structure. In the next section, we provide information on the evolution of female labor supply and discuss some special features of the Swedish labor market. Section 3 contains a theoretical framework and the identification strategy. Section 4 presents data, descriptive statistics, and some graphical analysis. The results are presented in section 5 and, finally, section 6 concludes the paper with a discussion. 


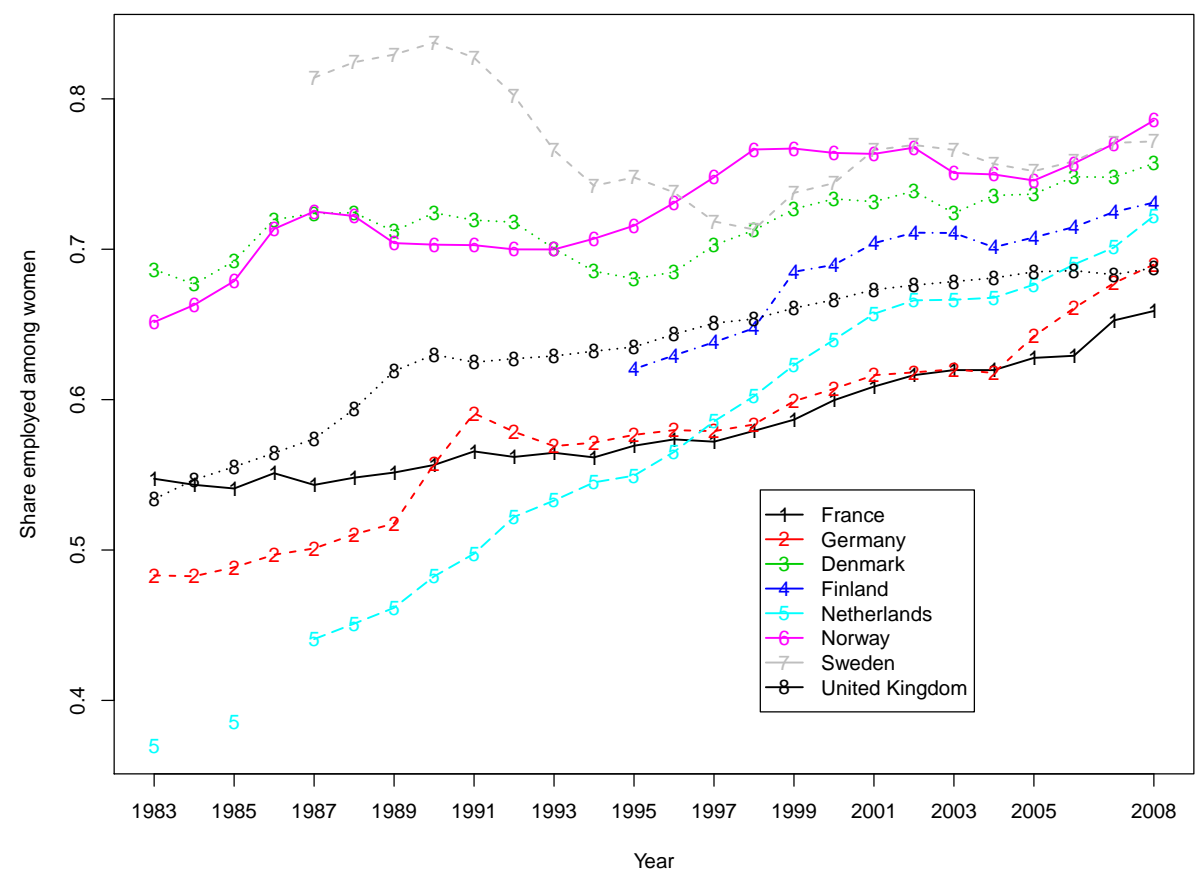

Figure 1: Labor force participation rate among women in eight European countries between 1983 and 2008. Source: Eurostat.

\section{Female labor supply and the Swedish labor market}

Figure 1 shows the female labor force participation in eight European countries for the period 1983 to 2008. From this figure, we can see that the participation rate in Sweden, together with the other Nordic countries, has been high and rather constant during the last decades. ${ }^{3}$ In the following we briefly present the Swedish context and discuss possible reasons for the high labor supply among Swedish women, seen from an international perspective.

Several reforms since the beginning of the 1970's have contributed to the high labor supply among women. The introduction of the individual

\footnotetext{
${ }^{3}$ In the early 1990s, Sweden experienced an economic crisis, which drastically decreased the labor supply among both men and women. Public expenditures were cut dramatically in the economic crisis. Since women are overrepresented in the public sector, this crisis affected women to somewhat larger degree than the males.
} 
tax system in 1971, whereby taxation of spouses was individualized, created large incentives for Swedish women to participate in the labor force. Selin (2009) concludes that the female labor supply increased by 10 percentage points due to this reform. ${ }^{4}$

Around the same time, in 1974, the parental leave system was introduced. The replacement rate for parental leave was from the very beginning proportional to forgone earnings, which probably has contributed to the high employment rate among women before entering parenthood. The generous replacement rate for parental leave and the flexibility of when to use the paid days probably also have contributed to the fact that most Swedish mothers labor market work while having small children. ${ }^{5}$ During the child's first 18 months, any one of the parents can stay at home on a full-time basis with job protection. Parents can take turns being on parental leave, as long as the total number of months on leave is at most 18 months per child. Thereafter, parents are allowed to reduce their working hours up to 25 percent until the child turns 8 years old (SFS 1995:584). Women use the parental insurance most: they take out 80 percent of the paid parental leave days (Försäkringskassan, 2011). In addition, 44 percent of all women in the ages $25-54$ work part-time $(<35$ hours per week). The corresponding share of men who work part-time is 10 percent. $^{6}$

In parallel to the institutional changes described above, there has been a rapid increase in the public provision of child care, especially during the 1980s. This may also have contributed to the high female labor supply, but it could also be a symptom of an increased demand for child care - a causal relationship between public provision of child care and female labor supply has not been established empirically.

Unfortunately, there are no public statistics on how the composition of the labor force with respect to age has changed over time. We do however have data on the participation rate of mothers with children younger than 7 years of age from the mid 1970s. Figure 2 shows the participation rate

\footnotetext{
${ }^{4}$ In this context it is interesting to note that, among the compared countries, Germany has the lowest female participation rate and in Germany couples are still taxed together.

${ }^{5}$ The introduction of the Swedish parental leave system has not (to our knowledge) been evaluated with respect to its effect on female labor supply.

${ }^{6}$ Source: Public statistics from Statistics Sweden, published on the web: http://www.scb.se/Pages/Article 332715.aspx
} 


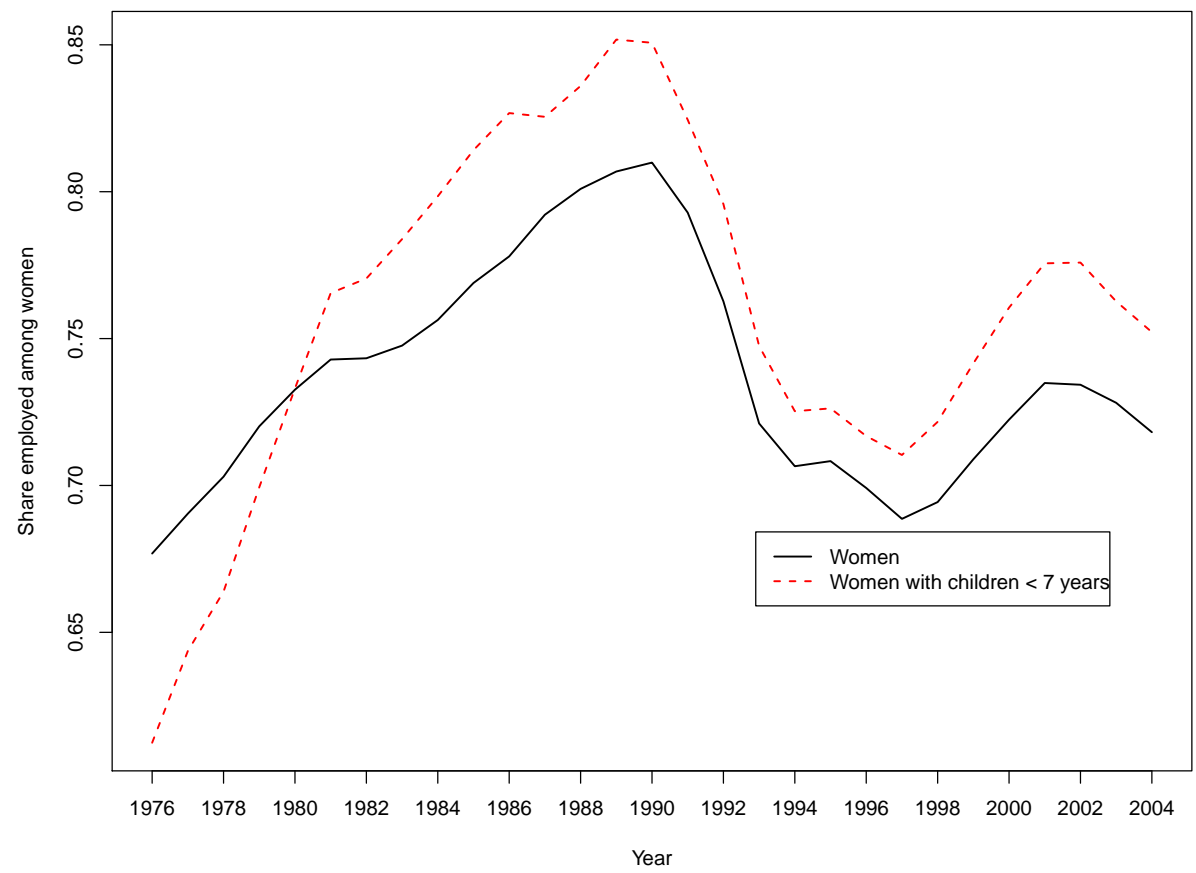

Figure 2: Labor force participation among all Swedish women and among women with children under 7 years between 1976 and 2004. Source: Statistics Sweden.

among Swedish women in general and mothers with young children in particular. This figure shows that the participation rate among women increased with 10 percentage points between the mid 1970s and the climax of the economy boom in 1990. Among women with pre-school children, the increase was about twice as large: almost 20 percentage points. From 1990 onwards, the participation rate is higher among women with pre-school children, than among women in general. This is most likely a cohort effect, that is, almost all young women participate in the labor force, while being a housewife is more common among older women.

\section{$3 \quad$ Identification and empirical strategy}

The choice of forming a family (i.e., having a child) is most often planned, both with whom and the timing. We think of a matching market where the matching depends on the partner's current and future productivity. 
As women are carrying the child for almost one year and women also are taking the lion part of the rearing of the child, it is reasonable to think of the decision of having a child as depending on the insurance coverage for the income loss during pregnancy and the child's childhood women face. This would mean that women are more likely to match with high-income men. ${ }^{7}$ Furthermore, the timing of when to have a child is probably a function of the attachment to the labor market. For instance, with income replacement proportional to the income loss while on parental leave (as is the case in Sweden), it is important to be employed when entering parenthood. In the estimation of the effect of parenthood, it is therefore important to control for factors correlated with both future incomes and the determinants for the decision of becoming a parent. ${ }^{8}$

The empirical strategy presented below allows us to identify the effect of parenthood on the gender gap in incomes and wages under the following optimizing behavior of the agents within the family: (i) The decision of having a child is formed on expectations about future incomes of the household, and (ii) parents solve their dual career problem by equalizing the marginal utility of time and effort in home production and market work (cf. Becker 1985). In this setting, a couple will have a child if the utility of having the child is larger than the expected loss of future household income. ${ }^{9}$

\footnotetext{
${ }^{7}$ However, in the Swedish context with quite high social insurance coverage and with parental benefits tied to pre birth income this kind of within family insurance solution may be less prevailing than in countries with lower social insurance coverage.

${ }^{8}$ An alternative is of course to find an instrument for parenthood. Seminal papers include Angrist and Evans (1998), who use parental preferences for mixed sibling-sex composition as a source of exogenous variation in family size, and Bronars and Grogger (1994), who employ twin births. The mixed-sex strategy measures the effect of a third child (compared to having two children), while using twin births, the focus is on the effect of two children (compared to one). There are also a few papers using instruments in the estimation of the effects for first time mothers. Hotz et al. (2005) and Miller (2011) both use variation from miscarriages. Miller (2011) uses conception as well. Klepinger et al. (1999) exploit age at menarche and regional policy variation in welfare generosity and access to family planning services. However, none of these studies has focused on average labor supply effects for mothers.

${ }^{9}$ This is intuitive, but also straightforward to show formally. Assume that utility is additively separable in consumption and the utility of having a child and that household maximize their utility in two steps: First, consumption is maximized conditional on having a child or not. In the second step, the household decides on having a child, based on the indirect utility in either state. The result from this simple model is that a household will have a child if the utility of having the child is larger than the expected
} 
In the present paper, we condition on having a child, which means that the condition above is satisfied for the couples in our analysis. The question then is if the expected income loss is unequally split within the couples. Below we describe the estimation problem and discuss assumptions for identification.

Let $\left\{Y_{j t}(1)\right\}_{t=0}^{T}, j=f, m$, be the potential income stream after becoming a parent in time period $t=0$ for females and males, and let $\left\{Y_{j t}(0)\right\}_{t=1}^{T}, j=f, m$, be the corresponding income stream if not becoming a parent. Furthermore, let $\left\{y_{j t}\right\}_{t=-L}^{T}, j=f, m$, be the observed income stream since labor market entry, which occurs $L$ years before receiving the first child. Our parameters of interest are the average expectations that couples have at $t=0$ regarding their within-couple income differences at time period $t>0$, for couples that became parents at $t=0$, defined as

$$
\begin{aligned}
\alpha_{t} & =\mathrm{EE}_{t=0}\left\{Y_{m t}(1)-Y_{f t}(1)-\left(Y_{m t}(0)-Y_{f t}(0)\right) \mid \text { parent=yes }\right\} \\
& \equiv \mathrm{EE}_{t=0}\left\{\widetilde{Z}_{t} \mid \text { parent=yes }\right\}
\end{aligned}
$$

where $\widetilde{Z}_{t} \equiv Y_{m t}(1)-Y_{f t}(1)-\left(Y_{m t}(0)-Y_{f t}(0)\right)$ is the potentially heterogeneous effect for a specific couple.

The gender differences in potential outcomes after having a child are thus by definition equal to

$$
\left(Y_{m t}(1)-Y_{f t}(1)\right)=\left(Y_{m t}(0)-Y_{f t}(0)\right)+\widetilde{Z}_{t}, t>0
$$

The interest is in estimating the effects for those who become parents and since we sample parents, $Y_{m t}(1)-Y_{f t}(1)=y_{m t}-y_{f t}$ is observed for $t>0 .{ }^{10}$ The main challenge therefore consists in estimating the stream of within-couple differences in income in the absence of a child, i.e., $\left\{\left(Y_{f, t}(0)-Y_{m, t}(0)\right)\right\}_{t=1}^{T}$. As we show in Appendix A, under the assumption that the timing of becoming parents is not based on expected changes in

loss of future household income.

${ }^{10}$ The interest is, thus, restricted to the effect for those becoming parents. If interest instead would have been in estimating an average treatment effect (i.e. for all potential couples) one would need to estimate $Y_{m t}(1)-Y_{f t}(1)$ for non parent and take into account that these non parents potentially get children in the future. Taking this kind of dynamic assignment into account severely complicates the estimation (cf. Fredriksson and Johansson 2008). 
the within income differences in the absence of a child, the estimand (1) can be consistently estimated by controlling for the income difference the year before parenthood, i.e. $y_{f,-1}-y_{m,-1}$.

We think that the identifying assumption is palatable but let us substantiate this claim somewhat. The identification strategy can be seen as a form of a difference-in-differences framework. Both groups (men and women) are affected by the treatment, but we allow the treatment magnitude to differ over the two groups. The identifying assumption is the same as in a traditional difference-in-differences setting, i.e., the intervention (having a child) must be strictly exogenous. That is, the timing of when to have a child should not be determined by expected shocks to the within-family gender difference in income or wage the couple would have experienced in absence of entering parenthood. This means that the timing of having a child should not be influenced by, for us, unobservable information about future income or wage trajectories of men in comparison with women or vise versa. For example, if the timing of having a child is determined by a promise of a promotion or advancement in the career of men, but not of women, our identification strategy fails. If anything, since parental benefits are tied to forgone earnings, the timing of parenthood may depend on positive shocks to the woman's income. However, as long as these shocks are not prospective they are observed in our data.

Consequently, although we cannot test whether the timing of parenthood is based on unobserved changes in expectations about future earnings, our set up allows us to test for observable pre-child trends. One advantage with our detailed longitudinal data is that the strict exogeneity assumption can be tested informally by examining the pre-parenthood trends in the within-couple income and wage differences. If the timing is based on gender biased shocks to incomes (or wages), we should observe this in data during the pre-birth period as a kink or a shift in the distribution of the gender gap in incomes or wages. Such informal tests are presented in the empirical section and the results suggest that the maintained assumption of no gender biased shocks is valid. 


\section{Data and descriptive statistics}

In the following we present the data used and some descriptive statistics including some graphical evidence of the effect.

\subsection{Data}

The data used in the analysis are taken from administrative registers covering all residents in Sweden between 16 and 65 years old during the period from 1986 to 2008. From these registers we have information about sex, age, labor market income, education, and family relations. We can link parents to their biological children and have access to birth year and birth order. Information about labor market income is based on the annual reports from the employers to the tax authorities. Thus, this amount reflects the total individual income from work without social transfers or tax reductions. Couples are traced from information about adults who are registered who have children together. To these data we have added information about monthly full-time equivalent wages. For the public sector, we have annual wage information on all persons employed. For the private sector, we have information on wages from a yearly 50 percent random sample. Thus, while our income data as well as wages for publicly employed cover all individuals, wage data for the private sector consists of cross-sectional representative samples each year.

From these data, we define couples who got their first-born child together during any of the years 1990 to 2002. To keep the number of observations manageable, we take a 10 percent sample (at couple level) from couples that get their first child during the various years. We then track these couples' labor market activities before and after the arrival of their first child. This implies that we can track each couple at least 4 years before and 6 years after the arrival of the first child. Parents who received their first child in 1990 are tracked at the most 18 years after the arrival of the first child, while parents whose first child was born in 2002 are tracked at the most 16 years before the birth-year of their first child. Table 1 summarizes the period of coverage of our data, measured in years. 
Table 1: Data coverage: number of years that we can follow parents.

\begin{tabular}{l|ccc}
\hline \hline Year of birth & 1990 & 1997 & 2002 \\
\hline Before birth-year & 4 & 11 & 16 \\
After birth-year & 18 & 11 & 6 \\
\hline \hline
\end{tabular}

Note: In the analysis, we use data for parents giving first birth in 19902002. Intermediate years not shown here in order to save space.

The panel enables us to study the dynamics of the within-couple difference in incomes and wages, i.e., the variation over the years before and after the arrival of the first child. Thus, we are able to draw conclusions about both short- and long-term effects of entering parenthood.

\subsection{Descriptive statistics}

In the analysis, we restrict the population to couples where both men and women have positive income two years before their first child is born. ${ }^{11}$ Table 2 presents the descriptive statistics (mean and standard deviation) for this population for the variables used in the analysis, both for levels and within-couple differences.

From the table we can see that the mean age when entering parenthood has increased over the study period. Among mothers, the average age when entering parenthood was 24.3 years of age in 1990 and about 26.6 years of age in 2000. The corresponding ages among men are 27.2 and 29.3, respectively. However, the male-female age difference of approximately 2 years is stable.

The number of years of education is around 11 years in 1990. Parents who have more than one child are more educated than those with just one child and mothers are in general more educated than fathers. The education level as well as the gender difference are both increasing over time.

The mean pre-birth income and wage are higher for men than for women. Parents who have more than one child have higher income and

\footnotetext{
${ }^{11}$ The analysis is repeated with a more restricted sample, consisting of fathers and mothers with an annual income of more than 50,000 SEK (about 4,500 Euro) two years before the first child is born. The results for this sample are qualitatively the same as the results displayed below.
} 
Table 2: Data description of all variables measured two years before birth year.

\begin{tabular}{|c|c|c|c|c|c|c|}
\hline \multirow{2}{*}{$\begin{array}{l}\text { Birth year, 1st child } \\
\text { Completed fertility }\end{array}$} & \multicolumn{2}{|c|}{1990} & \multicolumn{2}{|c|}{1995} & \multicolumn{2}{|c|}{2000} \\
\hline & $1 \mathrm{ch}$. & $\geq 2 \mathrm{ch}$ & $1 \mathrm{ch}$. & $\geq 2 \mathrm{ch}$ & $1 \mathrm{ch}$. & $\geq 2 \mathrm{ch}$. \\
\hline age, father & 26.6 & 26.2 & 28.8 & 27.7 & 29.3 & 28.4 \\
\hline st.dev. & 6.08 & 4.49 & 6.15 & 4.46 & 6.19 & 4.23 \\
\hline age, mother & 24.3 & 24 & 26.9 & 25.4 & 27.2 & 26.4 \\
\hline st.dev. & 5.79 & 3.87 & 5.47 & 3.74 & 5.7 & 3.81 \\
\hline age, (father - mother) & 2.28 & 2.26 & 1.97 & 2.31 & 2.11 & 1.94 \\
\hline st.dev. & 4.11 & 3.37 & 4.35 & 3.51 & 4.24 & 3.37 \\
\hline educ, father (years) & 11.1 & 11.6 & 11.7 & 12.2 & 11.9 & 12.6 \\
\hline st.dev. & 2.06 & 2.07 & 2.24 & 2.16 & 2.17 & 2.13 \\
\hline educ, mother (years) & 11 & 11.7 & 11.8 & 12.3 & 12 & 13 \\
\hline st.dev. & 1.96 & 1.91 & 1.99 & 1.9 & 2.27 & 2.17 \\
\hline educ, (father - mother) & 0.0854 & -0.0451 & -0.0788 & -0.0397 & -0.0633 & -0.393 \\
\hline st.dev. & 2.17 & 2.15 & 2.25 & 2.12 & 2.27 & 2.2 \\
\hline inc, father (SEK/year) & 174,080 & 191,751 & 183,282 & 193,221 & 219,893 & 242,179 \\
\hline st.dev. & 98,099 & 94,172 & 115,715 & 103,318 & 138,274 & 135,068 \\
\hline inc, mother (SEK/year) & 130,968 & 146,101 & 140,615 & 148,621 & 157,985 & 178,463 \\
\hline st.dev. & 78,855 & 67,186 & 84,905 & 80,613 & 107,950 & 97,517 \\
\hline inc, (father - mother) & 43,112 & 45,650 & 42,667 & 44,600 & 61,908 & 63,716 \\
\hline st.dev. & 93,191 & 95,938 & 109,281 & 108,926 & 139,128 & 135,151 \\
\hline \multirow[t]{2}{*}{ no. couples } & 691 & 2,904 & 495 & 1,992 & 474 & 2,068 \\
\hline & \multicolumn{6}{|c|}{ Restricted sample on wages } \\
\hline wage, father (SEK/month) & 18,888 & 18,787 & 19,288 & 19,090 & 23,033 & 23,283 \\
\hline st.dev. & 6,621 & 5,641 & 6,297 & 5,088 & 7,485 & 7,847 \\
\hline wage, mother (SEK/month) & 15,529 & 15,323 & 16,186 & 15,934 & 19,454 & 18,970 \\
\hline st.dev. & 3,243 & 3,161 & 3,171 & 2,992 & 4,832 & 3,997 \\
\hline wage, (father - mother) & 3,503 & 2,927 & 3,171 & 2,807 & 3,145 & 4,138 \\
\hline st.dev. & 7,132 & 5,430 & 6,038 & 4,573 & 6,746 & 7,615 \\
\hline no. couples & 92 & 459 & 104 & 416 & 99 & 480 \\
\hline
\end{tabular}

Note: Income and wages are measured in SEK in 2008 prices. The December, 2008 exchange rate was approximately 11 SEK for one Euro.

wages than those with just one child. The income and wages are increasing over time and the gender difference is increasing in absolute value 


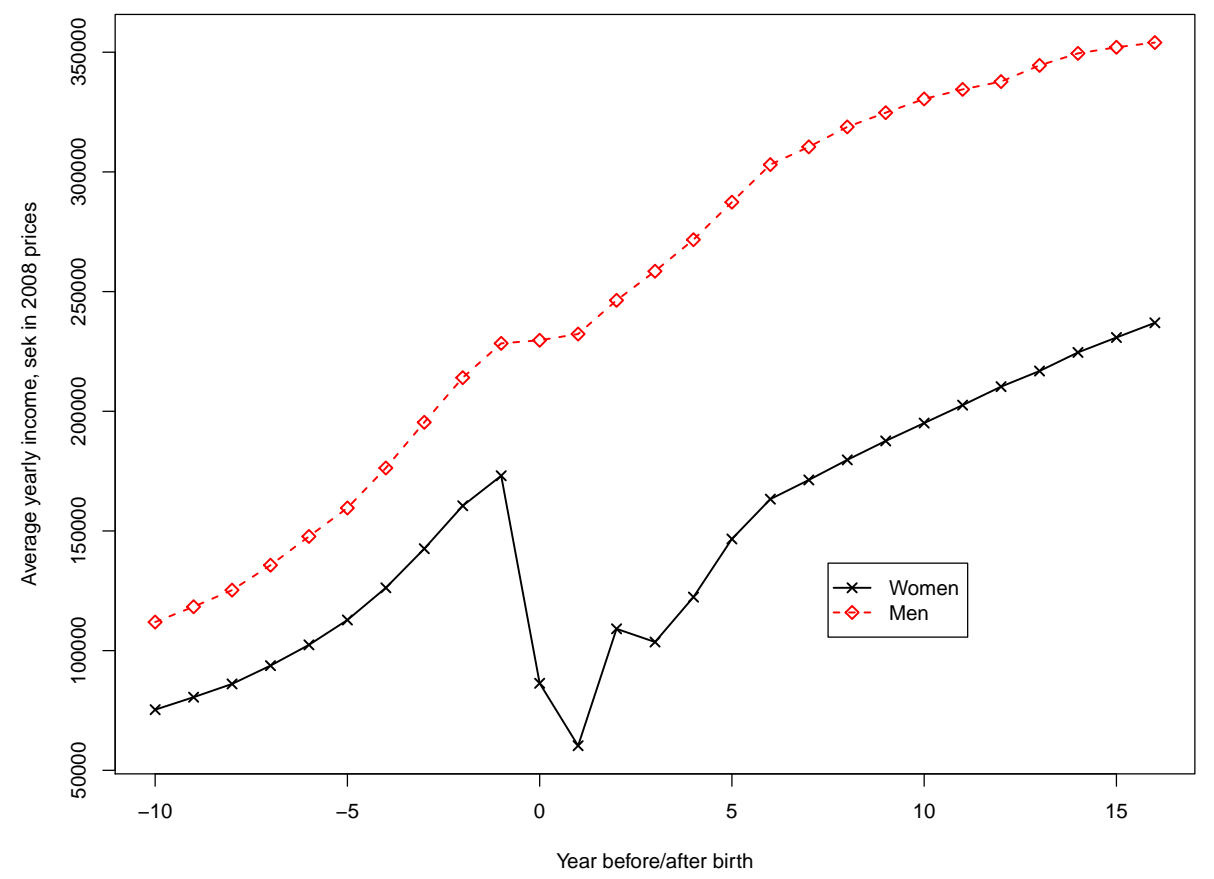

Figure 3: Average yearly income for women and men within matched couples before and after receiving their first child.

over time. ${ }^{12}$ The higher average income and wages of men are accompanied with larger standard deviations; the variation in the income and wages among men is greater than the corresponding wages and income among women.

The most interesting aspect in Table 2 is that the standard deviations of the within-couple differences on all variables are smaller or in parity with the standard deviation of the father. This fact provides evidence of a positive assortative mating in Sweden. It also provides support in favor for the suggested analysis in removing unobservables that are potentially correlated with parenthood and the dependent variables.

\subsection{Graphical evidence}

Before presenting our formal analysis we provide some first-step evidence by graphically examining the raw within-couple gap in income and wages

\footnotetext{
${ }^{12}$ Incomes and wages are measured in year 2008 prices, so these changes reflect realincome increases.
} 


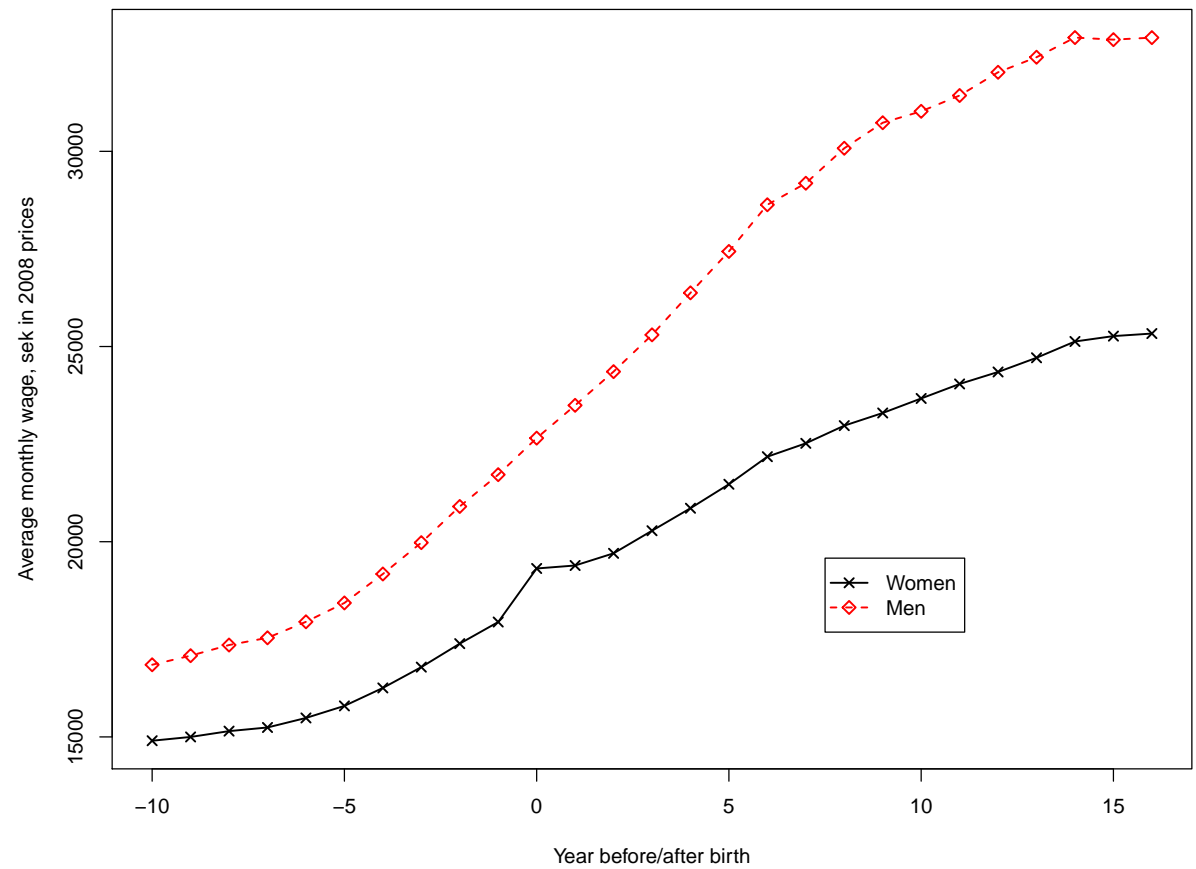

Figure 4: Average monthly wage for women and men within matched couples before and after receiving their first child.

over time. The patterns shown in Figures 3 and 4 reveal that before the arrival of the first child, the income and wage trajectory of the parents are parallel, suggesting no gender-specific trend over time. Men have higher pre-birth wage and income. After the arrival of the first child there is a dramatic change. First we have a sharp drop in the income among women due to their longer parental leave. After about 6 years women are back in a track parallel to the one of men, but at a substantially lower level. There is no corresponding drop in wages, suggesting that there is no direct wage penalty of being on parental leave. ${ }^{13} 14$ However, in the long run, the wage trajectory of mothers is much worse than that of men. In order to study

\footnotetext{
${ }^{13}$ For wage we do not have observations for all couples for all time periods. We observe all public employees, however only a yearly random sample of 50 percent of the private employees are observed. This could potentially be a problem interpreting the first shortrun effect if for example women in the public sector return to work faster after giving birth than women in the private sector. However, it should not be a problem interpreting the long-term effects.

${ }^{14}$ According to Swedish law, parental leave should per see not affect the wage negatively.
} 
the dynamics in more detail, we now turn to the formal analysis.

\section{Results}

In this section, we present estimation results, starting with the average effect of parenthood for our sample at different time periods after the arrival of the first child. Then, we turn to the heterogeneous effects estimated with quantile regressions.

The take-home message from section 3 is that the estimand (1) can be consistently estimated by controlling for the income difference the year before parenthood, i.e. $y_{m,-1}-y_{f,-1}$. As in the traditional difference-indifferences setting, we could informally test for the strict exogeneity assumption by studying the pre-parenthood trends in incomes. The result from this exercise shows that this maintained assumption seems plausible (see Figures 3 and 4). However, in order to more formally test the assumption, we use incomes two years preceding birth in the estimations.

To estimate the parameters of interest and to test the identifying assumption at the same time, we use the following specification:

$\left(\ln y_{i m t}-\ln y_{i f t}\right)-\left(\ln y_{i m-2}-\ln y_{i f-2}\right)=c+\sum_{j=0}^{18} \alpha_{j} \mathbf{1}_{t=j}+\boldsymbol{x}_{\boldsymbol{i t}}^{\prime} \boldsymbol{\beta}+u_{i t}, t \geq-1$,

where $i$ denotes couple $i, \boldsymbol{x}_{\boldsymbol{i t}}$ is a $k \times 1$ vector of covariates for couple $i$ in time $t, \mathbf{1}_{t=j}=1$ if $t=j$ and zero otherwise, and $u_{i t}$ is an error term (for details on identification see Appendix A). The parameters of interests $\alpha_{j}$ for $j=0,1, \ldots, 18$, identify the effects of parenthood on the gender income gap at the year of birth and up to 18 years after the birth of the child, relative to the pre-child gender income gap. The intercept $c$ gives an estimate of the pre-child change in the gender income gap, and thus if the estimate for $c$ is insignificant, we cannot reject the null hypothesis of strict exogeneity. Note that by using the log transformation of income, we are essentially modeling the percentage gender gap in income. The parameters identify, for each year after the birth-year, the change in the percentage gender gap in comparison to the pre-birth gap. 


\subsection{Average effects}

The estimation results for income are presented in the left-hand part of Table $3 .^{15}$ The first column presents results estimated without any control variables. The second column presents results when we control for calendaryear effects and the estimates presented in the third column are from a model in which we also have included the within-couple wage gap and the difference in years of education, measured two years before the birth of the first child.

It is quite obvious that we should control for calendar year in the estimation. Our data cover a long period and we therefore would like to control for different shocks in the economy that might affect women and men differently. However, from a theoretical or empirical point it is difficult to argue that we should add couple-specific control variables. What matters is the information the couple base their decision on. If the couple makes predictions that the wage profile is steeper for younger individuals (the women) or for more educated individuals, then we should control for these differences. It is, however, not obvious that the couples make these conditional predictions. We therefore choose to present the estimates from all three specifications: 1) without controls, 2) adding calender effects and 3) adding the full set of controls (see Table 3). The results are reassuringly robust as the parameters of interests in all three model specifications tell the same story and all estimates are statistically significant at the one percent level. The result regarding the intercept for both incomes and wages differs however.

When we do not control for covariates, the average income growth the year before parenthood of the men is lower than that of the women. However, when covariates are added, the unconditional average income growth of men and women are the same. The result when using wages is the opposite. There is no difference in average wage growth the year before parenthood when adding covariates, but an increase in the wage growth the year before parenthood for men when adding the controls. The im-

\footnotetext{
${ }^{15}$ Estimation is performed with ordinary least squares (OLS). Standard errors are estimated with a robust covariance matrix (White 1982). We have also estimated standard errors by clustering on household. The inference is qualitatively the same with the two types of estimators of the standard errors.
} 
plication of these model tests is that the wage-effect inference should be based

Table 3: Yearly effects of family formation in year $t=0$ on the withincouple change in the gender gap in income and wages. Outcome variable $\left(\ln y_{i m t}-\ln y_{i f t}\right)-\left(\ln y_{i m-2}-\ln y_{i f-2}\right)$

\begin{tabular}{|c|c|c|c|c|c|c|}
\hline & \multicolumn{3}{|c|}{ Yearly income } & \multicolumn{3}{|c|}{ Monthly wages } \\
\hline & $\begin{array}{c}\text { No } \\
\text { controls }\end{array}$ & $\begin{array}{c}\text { Calender } \\
\text { year }\end{array}$ & $\begin{array}{c}\text { Full set } \\
\text { of controls }\end{array}$ & $\begin{array}{c}\text { No } \\
\text { controls }\end{array}$ & $\begin{array}{c}\text { Calender } \\
\text { year }\end{array}$ & $\begin{array}{l}\text { Full set } \\
\text { of controls }\end{array}$ \\
\hline intercept & $\begin{array}{c}-0.101^{* * *} \\
(0.0122)\end{array}$ & $\begin{array}{c}-0.0987^{* * *} \\
(0.0299)\end{array}$ & $\begin{array}{c}0.0154 \\
(0.0306)\end{array}$ & $\begin{array}{c}0.00479^{*} \\
(0.00218)\end{array}$ & $\begin{array}{c}0.00734 \\
(0.00743)\end{array}$ & $\begin{array}{l}0.0315^{* * *} \\
(0.00772)\end{array}$ \\
\hline year 0 & $\begin{array}{l}1.355^{* * *} \\
(0.0220)\end{array}$ & $\begin{array}{l}1.368^{* * *} \\
(0.0226)\end{array}$ & $\begin{array}{l}1.365^{* * *} \\
(0.0226)\end{array}$ & $\begin{array}{c}0.0194^{* * *} \\
(0.00504)\end{array}$ & $\begin{array}{c}0.0204^{* * *} \\
(0.00513)\end{array}$ & $\begin{array}{l}0.0177^{* * *} \\
(0.00527)\end{array}$ \\
\hline year 1 & $\begin{array}{l}2.385^{* * *} \\
(0.0260)\end{array}$ & $\begin{array}{l}2.391^{* * *} \\
(0.0270)\end{array}$ & $\begin{array}{l}2.383^{* * *} \\
(0.0269)\end{array}$ & $\begin{array}{c}0.0268^{* * *} \\
(0.00450)\end{array}$ & $\begin{array}{c}0.0260^{* * *} \\
(0.00467)\end{array}$ & $\begin{array}{l}0.0243^{* * *} \\
(0.00472)\end{array}$ \\
\hline year 2 & $\begin{array}{l}1.414^{* * *} \\
(0.0257)\end{array}$ & $\begin{array}{l}1.416^{* * *} \\
(0.0272)\end{array}$ & $\begin{array}{l}1.405^{* * *} \\
(0.0272)\end{array}$ & $\begin{array}{l}0.0400^{* * *} \\
(0.00446)\end{array}$ & $\begin{array}{l}0.0395^{* * *} \\
(0.00473)\end{array}$ & $\begin{array}{l}0.0367^{* * *} \\
(0.00478)\end{array}$ \\
\hline year 3 & $\begin{array}{l}1.601^{* * *} \\
(0.0264)\end{array}$ & $\begin{array}{l}1.592^{* * *} \\
(0.0283)\end{array}$ & $\begin{array}{l}1.578^{* * *} \\
(0.0283)\end{array}$ & $\begin{array}{l}0.0444^{* * *} \\
(0.00484)\end{array}$ & $\begin{array}{l}0.0454^{* * *} \\
(0.00513)\end{array}$ & $\begin{array}{l}0.0422^{* * *} \\
(0.00513)\end{array}$ \\
\hline year 4 & $\begin{array}{l}1.229^{* * *} \\
(0.0259)\end{array}$ & $\begin{array}{l}1.226^{* * *} \\
(0.0282)\end{array}$ & $\begin{array}{l}1.208^{* * *} \\
(0.0281)\end{array}$ & $\begin{array}{l}0.0566^{* * *} \\
(0.00485)\end{array}$ & $\begin{array}{l}0.0590^{* * *} \\
(0.00521)\end{array}$ & $\begin{array}{l}0.0551^{* * *} \\
(0.00519)\end{array}$ \\
\hline year 5 & $\begin{array}{l}0.908^{* * *} \\
(0.0254)\end{array}$ & $\begin{array}{l}0.942^{* * *} \\
(0.0282)\end{array}$ & $\begin{array}{l}0.919^{* * *} \\
(0.0281)\end{array}$ & $\begin{array}{l}0.0655^{* * *} \\
(0.00502)\end{array}$ & $\begin{array}{l}0.0684^{* * *} \\
(0.00548)\end{array}$ & $\begin{array}{l}0.0638^{* * *} \\
(0.00543)\end{array}$ \\
\hline year 6 & $\begin{array}{l}0.762^{* * *} \\
(0.0253)\end{array}$ & $\begin{array}{l}0.833^{* * *} \\
(0.0285)\end{array}$ & $\begin{array}{l}0.806^{* * *} \\
(0.0284)\end{array}$ & $\begin{array}{l}0.0717^{* * *} \\
(0.00508)\end{array}$ & $\begin{array}{l}0.0754^{* * *} \\
(0.00565)\end{array}$ & $\begin{array}{c}0.0702^{\text {*** }} \\
(0.00559)\end{array}$ \\
\hline year 7 & $\begin{array}{l}0.677^{* * *} \\
(0.0263)\end{array}$ & $\begin{array}{l}0.756^{* * *} \\
(0.0295)\end{array}$ & $\begin{array}{l}0.723^{* * *} \\
(0.0294)\end{array}$ & $\begin{array}{l}0.0824^{* * *} \\
(0.00553)\end{array}$ & $\begin{array}{l}0.0868^{* * *} \\
(0.00606)\end{array}$ & $\begin{array}{l}0.0808^{* * *} \\
(0.00596)\end{array}$ \\
\hline year 8 & $\begin{array}{l}0.584^{* * *} \\
(0.0272)\end{array}$ & $\begin{array}{l}0.690^{* * *} \\
(0.0306)\end{array}$ & $\begin{array}{l}0.653^{* * *} \\
(0.0305)\end{array}$ & $\begin{array}{l}0.0816^{* * *} \\
(0.00593)\end{array}$ & $\begin{array}{l}0.0862^{* * *} \\
(0.00650)\end{array}$ & $\begin{array}{c}0.0795^{* * *} \\
(0.00639)\end{array}$ \\
\hline year 9 & $\begin{array}{l}0.496^{* * *} \\
(0.0283)\end{array}$ & $\begin{array}{l}0.628^{* * *} \\
(0.0319)\end{array}$ & $\begin{array}{l}0.586^{* * *} \\
(0.0318)\end{array}$ & $\begin{array}{l}0.0846^{* * *} \\
(0.00634)\end{array}$ & $\begin{array}{l}0.0905^{* * *} \\
(0.00694)\end{array}$ & $\begin{array}{c}0.0839^{* * *} \\
(0.00679)\end{array}$ \\
\hline year 10 & $\begin{array}{l}0.447^{* * *} \\
(0.0298)\end{array}$ & $\begin{array}{l}0.603^{* * *} \\
(0.0336)\end{array}$ & $\begin{array}{l}0.556^{* * *} \\
(0.0335)\end{array}$ & $\begin{array}{l}0.0901^{* * *} \\
(0.00696)\end{array}$ & $\begin{array}{l}0.0971^{* * *} \\
(0.00761)\end{array}$ & $\begin{array}{c}0.0899^{* * *} \\
(0.00745)\end{array}$ \\
\hline year 11 & $\begin{array}{l}0.386^{* * *} \\
(0.0315)\end{array}$ & $\begin{array}{l}0.559^{* * *} \\
(0.0356)\end{array}$ & $\begin{array}{l}0.506^{* * *} \\
(0.0355)\end{array}$ & $\begin{array}{c}0.0980^{* * *} \\
(0.00740)\end{array}$ & $\begin{array}{c}0.107^{* * *} \\
(0.00808)\end{array}$ & $\begin{array}{c}0.0983^{* * *} \\
(0.00789)\end{array}$ \\
\hline year 12 & $\begin{array}{l}0.313^{* * *} \\
(0.0332)\end{array}$ & $\begin{array}{l}0.499^{* * *} \\
(0.0378)\end{array}$ & $\begin{array}{l}0.443^{* * *} \\
(0.0377)\end{array}$ & $\begin{array}{l}0.0977^{* * *} \\
(0.00790)\end{array}$ & $\begin{array}{c}0.108^{* * *} \\
(0.00866)\end{array}$ & $\begin{array}{l}0.100^{* * *} \\
(0.00842)\end{array}$ \\
\hline year 13 & $\begin{array}{l}0.297^{* * *} \\
(0.0355)\end{array}$ & $\begin{array}{l}0.485^{* * *} \\
(0.0403)\end{array}$ & $\begin{array}{l}0.425^{* * *} \\
(0.0402)\end{array}$ & $\begin{array}{c}0.106^{* * *} \\
(0.00879)\end{array}$ & $\begin{array}{c}0.118^{* * *} \\
(0.00956)\end{array}$ & $\begin{array}{l}0.109^{* * *} \\
(0.00930)\end{array}$ \\
\hline year 14 & $0.234^{* * *}$ & $0.430^{* * *}$ & $0.367^{* * *}$ & $0.101^{* * *}$ & $0.116^{* * *}$ & $0.105^{* * *}$ \\
\hline
\end{tabular}

Continued on Next Page... 
Table 3 - Continued

\begin{tabular}{|c|c|c|c|c|c|c|}
\hline & \multicolumn{3}{|c|}{ Yearly income } & \multicolumn{3}{|c|}{ Monthly wages } \\
\hline & $\begin{array}{c}\text { No } \\
\text { controls }\end{array}$ & $\begin{array}{c}\text { Calender } \\
\text { year }\end{array}$ & $\begin{array}{c}\text { Full set } \\
\text { of controls }\end{array}$ & $\begin{array}{c}\text { No } \\
\text { controls }\end{array}$ & $\begin{array}{l}\text { Calender } \\
\text { year }\end{array}$ & $\begin{array}{c}\text { Full set } \\
\text { of controls }\end{array}$ \\
\hline & $(0.0382)$ & $(0.0432)$ & $(0.0430)$ & $(0.00963)$ & $(0.0104)$ & $(0.0102)$ \\
\hline \multirow[t]{2}{*}{ year 15} & $0.204^{* * *}$ & $0.416^{* * *}$ & $0.352^{* * *}$ & $0.103^{* * *}$ & $0.119^{* * *}$ & $0.109^{* * *}$ \\
\hline & $(0.0423)$ & $(0.0474)$ & $(0.0472)$ & $(0.0115)$ & $(0.0122)$ & $(0.0119)$ \\
\hline \multirow[t]{2}{*}{ year 16} & $0.151^{* *}$ & $0.390^{* * *}$ & $0.325^{* * *}$ & $0.0931^{* * *}$ & $0.109^{* * *}$ & $0.0978^{* * *}$ \\
\hline & $(0.0476)$ & $(0.0528)$ & $(0.0526)$ & $(0.0133)$ & $(0.0141)$ & $(0.0137)$ \\
\hline \multirow[t]{2}{*}{ year 17} & 0.0707 & $0.344^{* * *}$ & $0.270^{* * *}$ & $0.0629^{* * *}$ & $0.0788^{* * *}$ & $0.0682^{* * *}$ \\
\hline & $(0.0584)$ & $(0.0636)$ & $(0.0633)$ & $(0.0167)$ & $(0.0175)$ & $(0.0169)$ \\
\hline \multirow[t]{2}{*}{ year 18} & -0.0565 & $0.228^{*}$ & 0.156 & $0.108^{* * *}$ & $0.127^{* * *}$ & $0.117^{* * *}$ \\
\hline & $(0.0845)$ & $(0.0899)$ & $(0.0894)$ & $(0.0259)$ & $(0.0267)$ & $(0.0256)$ \\
\hline calender year & no & yes & yes & no & yes & yes \\
\hline pre-child contr. & no & no & yes & no & no & yes \\
\hline$N$ & 523,428 & 523,428 & 523,428 & 44,905 & 44,905 & 44,905 \\
\hline$R^{2}$ & 0.022 & 0.023 & 0.031 & 0.014 & 0.015 & 0.063 \\
\hline $\operatorname{adj} . R^{2}$ & 0.022 & 0.023 & 0.031 & 0.014 & 0.015 & 0.062 \\
\hline
\end{tabular}

${ }^{*} p<0.05,{ }^{* *} p<0.01,{ }^{* * *} p<0.001$

Note: Estimation by ordinary least squares. The full set of controls consists of calendar year dummies; within-couple age gap; and pre-child within-couple differences in education. Standard errors within parentheses are estimated with a robust covariance matrix (White 1982).

on the second column, and the income-effect inference the third. However, since there is no qualitative difference in results we only discuss the results in the third and sixth columns, i.e., the estimates with the full set of control variables.

We start by discussing the results for the income variable, presented in the left-hand part of Table 3. During the birth-year (year 0) the parameter estimate of the change in the income gap is 1.37. The interpretation is that the gender gap in income is approximately 137 percentage points larger during the first year as parents, in comparison to its pre birth level. ${ }^{16}$ What does this mean in absolute terms? Assume that in the absence of a child fathers' average income would have remained at the same level as two years

\footnotetext{
${ }^{16}$ The log-difference, which we use in estimation, is a good approximation of the percentage difference only for small differences. Therefore, while the percentage points interpretation illustrates the order of magnitude of the effect, at these large levels, the approximation is not precise.
} 
before the birth. Using estimates from the description in Table 2, fathers of more than two children with the first child born in 1990 earned 191,751 SEK in 2008 prices (approx. 17,400 Euro ${ }^{17}$ ). ${ }^{18}$ Then the parameter estimate of 1.37 would imply that women's average yearly income shrinks to 71,483 SEK, i.e., a gender income gap of 120,268 SEK. During the year the child turns one year old, the parameter estimate is even higher (2.38). This huge average estimate reflects the fact that women take out the largest part of the parental leave, and due to the design of the parental-leave insurance in Sweden, there is an almost complete withdrawal of women from the labor market. After the second year since birth, the negative effect of parenthood on the gender gap in income decreases for every subsequent year, as women return to work. However, women never catch-up: 15 years after the first child was born, the gender gap in income is still about 35 percentage points higher than before the child was born.

Turning to the corresponding effects on wages, shown in the right-hand part of Table 3, we have the following results. During the child's first two years, the change in the wage gap is small, which potentially reflects that mothers with higher wages return to work after giving birth faster than mothers with lower wages. However, in the long run, almost all Swedish mothers have returned to the labor market and from about 10 years after the birth-year an onwards, the wage gap (relative to the pre-child wage gap) remains at a constant level of about 10 percentage points in favor of the men.

\subsection{Heterogeneous effects}

In this section we are interested in heterogeneous effects with respect to the within-household earnings capacity in absence of children, i.e., the counterfactual dispersion of relative incomes and wages over time within the household. To this end, we estimate quantile regressions. We use the same specification (with the full set of controls) as in Table $3 .{ }^{19}$

\footnotetext{
${ }^{17}$ We use the December, 2008 exchange rate of approximately 11 SEK for one Euro.

${ }^{18}$ Note that our specification does not allow us to estimate fathers' or mothers' changes separately.

${ }^{19}$ We obtain qualitatively the same results without control variables.
} 

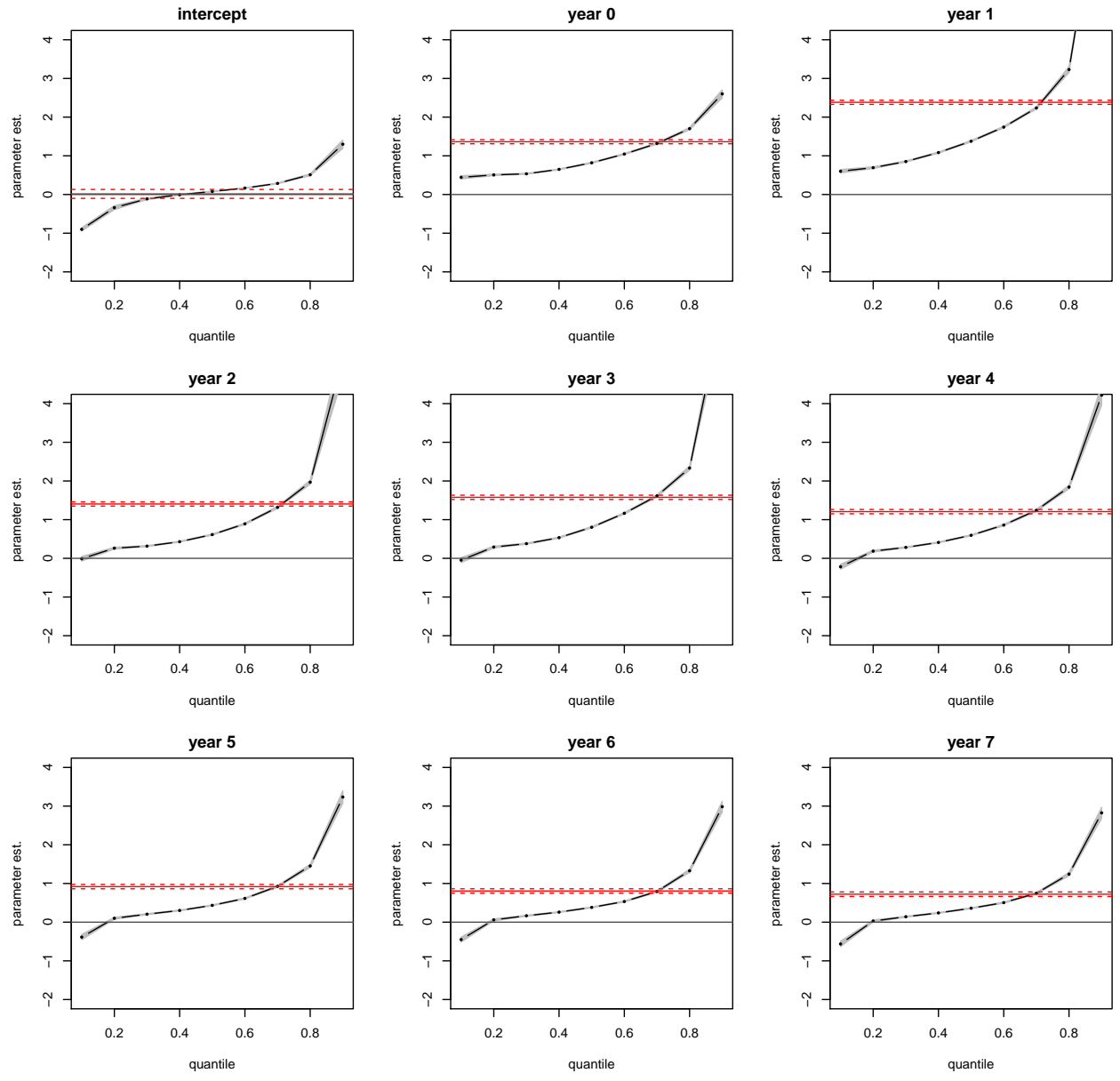

Figure 5: The effect of family formation on the change in the within-couple income gap: intercept and years 0 through 7 .

Note: The effect is measured in various parts of the conditional distribution of the outcome variable $\left(\ln y_{i m t}-\ln y_{i f t}\right)-\left(\ln y_{i m-2}-\ln y_{i f-2}\right), t \geq-1$ with $y_{i m t / i f t}$ being the yearly income of the male/female within each couple in year $t$. We use quantile regressions with the following control variables: calendar year dummies; within-couple age gap; and pre-child within-couple differences in education. The dashed curve with dots represents quantile-regression estimates for different quantiles on the $\mathrm{X}$-axis, with corresponding 95\% CI (shaded area). For reference, the OLS-estimate with the same controls is included (straight line with the corresponding dashed 95\% CI). The various graphs represent different parameters: The intercept captures the change in the gender gap between the first two years before having a child. The rest of the parameters identify, for each year after the birth-year, the percentage change in the gender gap in comparison to the pre-birth gap. 

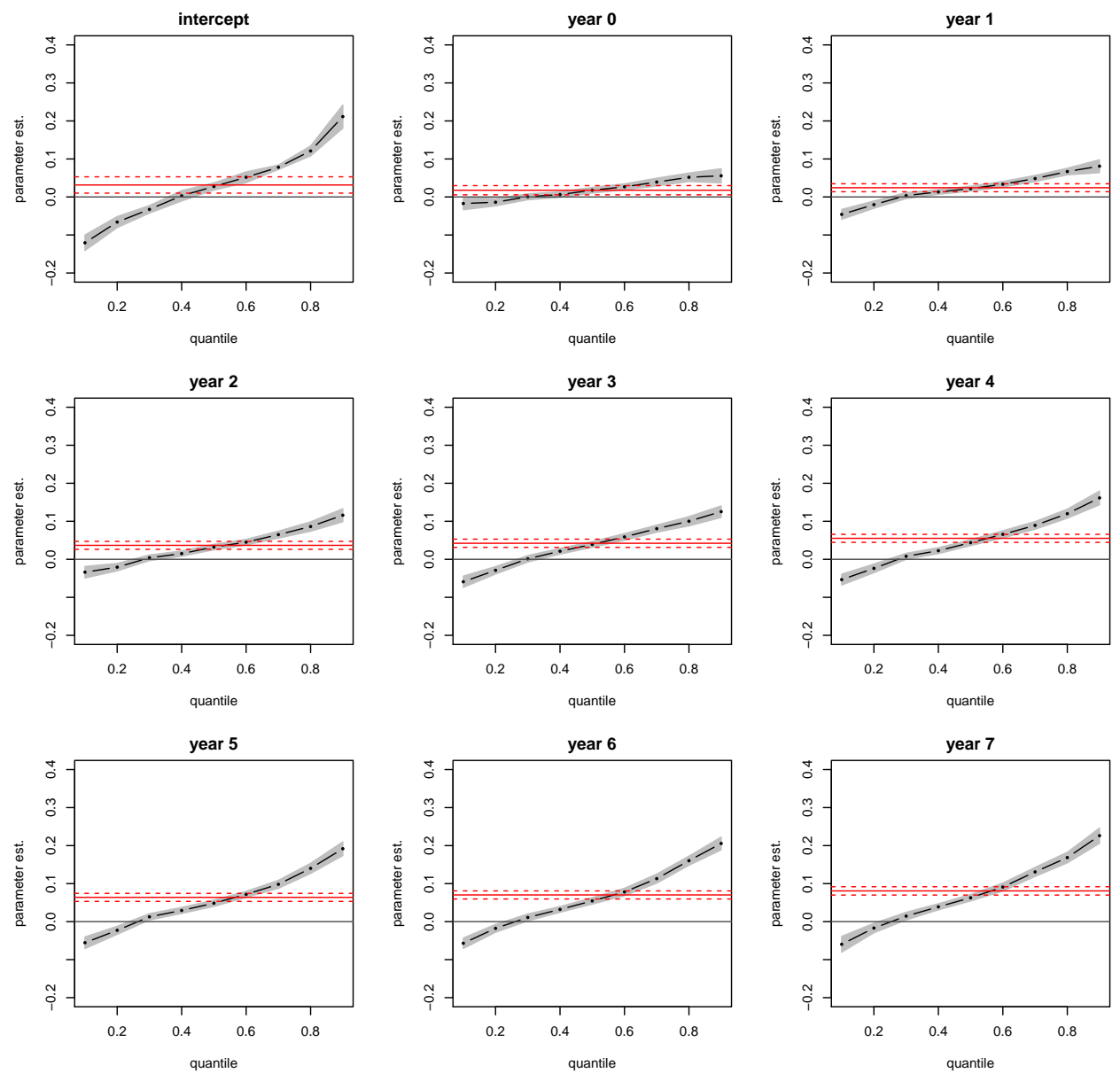

Figure 6: The effect of family formation on the change in the within-couple wage gap: intercept and years 0 through 7 .

Note: The effect is measured in various parts of the conditional distribution of the outcome variable $\left(\ln y_{i m t}-\ln y_{i f t}\right)-\left(\ln y_{i m-2}-\ln y_{i f-2}\right), t \geq-1$ with $y_{i m t / i f t}$ being the monthly wage of the male/female within each couple in year $t$. We use quantile regressions with the following control variables: calendar year dummies; within-couple age gap; and pre-child within-couple differences in education. The dashed curve with dots represents quantile-regression estimates for different quantiles on the X-axis, with corresponding 95\% CI (shaded area). For reference, the OLS-estimate with the same controls is included (straight line with the corresponding dashed 95\% CI). The various graphs represent different parameters: The intercept captures the change in the gender gap between the first two years before having a child. The rest of the parameters identify, for each year after the birth-year, the percentage change in the gender gap in comparison to the pre-birth gap. 
For each year after the arrival of the first child, we estimate the effect of parenthood in the 10th to 90th percentile of the conditional distribution of the within-couple counterfactual gaps in income and wage trajectories. In the lower end of the conditional distribution, we have mothers with the most favorable counterfactual income and wage trajectories in relation to their partners. The opposite is true for couples in the upper part of the conditional distribution.

We start by presenting the results on the change in the within-couple gap in income over time. Figure 5 presents quantile regression estimates for the intercept and yearly effects for year 0 to 7 . The straight lines represent the OLS-estimates (cf. Table 3) with corresponding confidence intervals (dashed lines). The estimates from the quantile regressions for different quartiles are depicted together with confidence intervals (the shaded area).

Before the arrival of the first child, the changes in the gender gap are symmetrically distributed around zero (the intercept); almost half of the households experienced an increased gender gap in favor of the men, while the other half of the households experienced the opposite, namely that women had a higher income increase than their spouses had. This is an important result as it suggests that the decision of having a child is not being based on, e.g., that the women had an unexpectedly bad income draw, or the opposite. We interpret this as a sign of the validity of our identification assumption, namely that the choice of having a child is strictly exogenous in our setting. During the first year as parents, all couples experience a higher increase in the income of the males (year 1). The change in this gender gap is smaller the better the counterfactual income trajectory the mothers have in comparison to their male partners. In other words: mothers with higher (within-couple) relative earnings capacity bear smaller short-term economic costs from having a child, compared to mothers with lower (within-couple) relative earnings capacity.

Looking at the longer run, we see that these heterogeneous effects are further enhanced. In year 7 , couples in the lowest part of the conditional distribution (the 10th percentile) even experienced a decreasing gender gap over time as an effect of parenthood. In other words: in couples where fathers would have had the worst relative income trajectory in the absence of children, fathers bear the largest economic cost of parenthood. In Figure 7 
in Appendix B, we show the results for years 8 through 18, where we see the same picture in the even longer run.

The results from the quantile regressions on wages are presented in Figure 6 (intercept and years 0-7) and in Figure 8 in Appendix B (years 8-18). In these estimations, the standard errors are higher than the standard errors in the estimation of the effects on income. The reason is that we do not have full data coverage for wages. However, we can draw the same conclusions from the results on wages as from the ones on income. The results are in line with the theoretical prediction on how the effect of parenthood varies across the conditional distribution if the decision of sharing the cost of parenthood depends on the comparative advantages within the couple. That is, the partner who has the smallest opportunity cost in terms of expected forgone earnings, bears the largest cost of parenthood, here in terms of forgone wage increase.

\section{Concluding discussion}

Our starting point for this work is the fact that the Swedish gender gap in earnings has been constant for the last 30 years, in spite of several changes in favor of women on the labor market. This stagnation coincides with women's full entrance on the labor market. These facts suggest that the constant gender gap is explained by causes not related to the labor market, but rather to unequal gender division of family responsibilities within the household.

We estimate both short- and long-term average effects of parenthood on the within-couple gender gap in income and wages. Furthermore, we focus on the importance of the match of couples: with whom one decides to form a family. Using quantile regressions, we also study how the effect of parenthood differs across the distribution of the gender gap in incomes and wages in the absence of having a child.

The main result is that parenthood affects men and women differently, which is in accordance with several earlier studies (e.g., Waldfogel, 1997; Buding and England, 2001; Loughren and Zissimopolus, 2008, Sasser, 2008, Kennerberg, 2007). But in contrast to earlier studies, we ask a somewhat different question, namely: what happens with the within-couple gender 
gap in incomes and wages after the arrival of the first child?

By restricting the question to effects on the within-couple gender gap, we are able to control for both observed and unobserved attributes of the partner which can be important if the labor supply of the partner changes as a response to parenthood. Using longitudinal data on labor supply of women in a fixed-effect estimation of the effect of becoming a mother would exaggerate the effect of parenthood on women's labor supply. The reason is that the change in the income of the partner is a confounder in the model since the fathers' incomes theoretically affect mothers' labor supply (cf. Mincer, 1966). ${ }^{20}$ Our approach allows us to estimate the average effect of parenthood across the distribution of parents' potential earnings and to study the dynamics of the effect by means of evaluating the effect for every subsequent year since the birth-year of the first child.

We find that 15 years after entering parenthood, the percentage malefemale gender gap in income has increased with 35 percentage points compared to its pre-child level. The corresponding increase for the gender gap in wages is 10 percentage points. The results from the quantile regressions suggest that the effect of parenthood on the male-female gap increases with the income and wage gap the couple would have experienced in absence of parenthood. The general message of this analysis is that the match of couples is crucial for the magnitude of the effect of parenthood on incomes and wages. That is, an important determinant for the negative effect of parenthood on women's incomes and wages is women's expected position within the family in terms of earnings potential.

This finding is in line with a collective labor supply model as in, e.g., Blundell et al. (2005). More recently, Cherchye et al. (2012) estimate a structural collective labor supply model with household production consisting of two domestic goods (parenting and general household work) on a rich time-use dataset from the Netherlands. They are able to estimate the extent to which the husband's Pareto weight in the household bargaining increases with an increase in his relative wage within the household, and find that the Pareto weight increases significantly with a relative wage

\footnotetext{
${ }^{20}$ Fathers' change in labour supply can theoretically go in either direction; Kennerberg (2007), for instance, finds that some fathers increase their labor supply when becoming a parent.
} 
increase. Similarly, we find that higher relative earnings potential of the fathers within the household imply a relative decrease (increase) in female labor supply (household production) due to parenthood. Our quantile regressions suggest that the size of the effects changes monotonically with the magnitude of the relative differences in earnings. We even find a negative effect of parenthood on the male-female gender gap in income for the 20 percent of the couples with the lowest male/female relative earnings potential. To sum up, receiving a first child implies a downward shift in at least one parent's labor supply because, by necessity, parenting requires time. What our results show is that relative potential earnings have a significant effect on whose labor supply decreases after the arrival of the first child, and by how much.

Note that these results are not compatible with a unitary model. In such a setting, although there would exist some weighting function that weighs together each household member's utility into a household utility function, by assumption, the relative weight is not a function of relative wages or income. Therefore, there is no logic in why the amount of female household production should change with the magnitude of the relative differences in potential earnings. For a list of earlier evidence against the unitary model, see section 5.5.1 in Browning et al. (2011).

How do our main results compare with evidence from macro data? We illustrate by using mid-career earnings for men and women. Taking data from the Swedish tax registers, we find that the percentage income difference between males of age 43 and females of age 41 was 47 percent in $2006 .^{21}$ We use 2006 for this example because in our dataset, 2006 is the year when we, on average in our sample, observe the incomes of mothers and fathers 15 years after child birth. Moreover, we show the percentage difference for the ages 43 for males and 41 for females, respectively, because these are the average parent ages at which the first child turns 15 years. Using our data of matched couples, the percentage income difference between fathers and mothers 15 years after the birth of the first child is 53 percent. In a way, we are thus explaining more of the gender gap than can be found in macro data. However, there is an obvious reason for this difference, namely that we sample parents. As previously documented in Boschini et al. (2011,

\footnotetext{
${ }^{21}$ Source: the table Louise for year 2006, Statistics Sweden.
} 
fig. 12), the mid-career earnings of single men in Sweden are significantly lower than the corresponding earnings for fathers. Furthermore, although there is a similar difference between single women and mothers, the latter is much smaller. Thus, it should be expected that the mid-career gender gap for our sample of parents is greater than for the whole population of parents and singles. Indeed, using official statistics once more, we find that the percentage income difference between males of age 43 and females of age 41 was 62 percent for parents in 2006. ${ }^{22}$ This number is larger than the 53 percent for parents in our data, but note that we have not taken into consideration the age of the child.

Loosely speaking, the observed gender income gap in macro data consists of a part that we explain in this paper, namely the effect of parenthood, as well as a number of other factors. Obviously, not all individuals have children, and as mentioned above, the gender gap is much smaller for nonparents. Yet, it is interesting to compare the magnitude of our parenthood effect estimate with the magnitude of the observed gender gap in macro data. It follows from the discussion above that our baseline estimate of a 35 percentage points increase in the within-couple income gender gap explains about three-fourths of the 47 percent gender gap observed in macro data.

Compared with previous studies of the gender gap between men and women within the same occupation, our estimate is much higher. Gender differences in family responsibilities are claimed to explain 39 percent of the gender gap among medical doctors (Sasser, 2005) and 40 percent of the gender gap among lawyers (Wood, Corcoran and Courant, 1993). However, given our previous results, this difference is to be expected. As our quantile regressions show (see section 5.2), mothers with lower relative earnings capacity bear higher economic costs from having a child, compared to mothers with higher relative earnings capacity. Arguably, in equally educated and high-skilled couples where both spouses are either physicians or lawyers, womens' relative income trajectory in absence of a child is higher than the average in the population.

We also find small short-term effects on the wage gender gap. Moreover, these effects increase with the age of the first child; after 15 years women

\footnotetext{
${ }^{22}$ The corresponding number for non-parents is 19 percent. Source: the table Louise for year 2006, Statistics Sweden.
} 
have 10 percent lower wages due to parenthood. Datta Gupta and Smith (2002) and Albrecht et al. (1999) study the effect of career interruptions due to child care, holding experience (labor supply) constant. These studies do not find any wage penalty of parental leave, at least not among women. ${ }^{23}$ Since earlier studies indicate no wage penalty for women of parental leave, we interpret our negative estimates on the gender gap in wages as an indirect effect of a gender differential effect of parenthood on effort on the labor market in terms of labor supply and labor market commitment. The Swedish social insurance allow for a generous job-protected leave; Swedish parents are allowed, with job protection, to reduce their working hours up to 25 percent until the child turns 8 years old. This opportunity is in particular used by Swedish mothers (see section 2). Thus, the wage effect we find is probably not explained by human capital depreciation while on leave, but rather to a less rapid human capital accumulation associated with part-time work among mothers.

The reason why women are taking larger responsibility for the family and for household work has received extensive attention in the literature. Akerlof and Kranton (2002) discuss the importance of gender identity, which could explain why men and women keep traditional gender roles. Our results emphasize the matching of couples as an important explanatory factor for the income gender gap. Men are on average two years older than women when entering parenthood. An age difference of two years implies two additional years of labor market experience, which in turn implies a higher earnings capacity on the labor market. ${ }^{24}$ If parents are myopic, ${ }^{25}$ this age gap may contribute to the unequal gender division of family responsibilities, simply because mothers have a lower immediate opportunity cost of staying at home.

Furthermore, we cannot exclude that there are gender differences in

\footnotetext{
${ }^{23}$ Albrecht et al. (1999) study whether the effect of a career interruption differs depending on reason for the break and they conclude that there is a wage penalty of parental leave for men but not for women. Their explanation is that there are different signal values of being on parental leave between men and women.

${ }^{24} \mathrm{In}$ addition, women are on average more educated than men, which would delay labor market entry even further.

${ }^{25}$ Engström, Kolm and Liang (2009) discuss the importance of present-biased preferences when parents divide their division of the parental leave. That is, mothers with present-biased preferences give a disproportionate high weight to the instantaneous utility (or disutility) of staying at home for child-care reasons.
} 
preferences for labor market work versus home production. For example, education and health investments in children have been shown to be more important for mothers than for fathers (Phipps and Burton, 2008; Thomas, 1990 and 1994). Thus, the spouse who cares the most about the joint good (children) will end up financing it the most (Pollak, 2005). In fact, newly presented evidence on the gender gap in earnings among associate lawyers in the United States show that the main explanation is a gender differential in performance, which in turn stems from a gender differential impact on performance in presence of preschool children (Azmat and Ferrer, 2012). Moreover, Azmat and Ferrer (2012) do not find gender differences regarding satisfaction in work recognition and opportunities for advancement among US lawyers. Taken together, as long as partner selection is based on a free choice, we cannot exclude that the gender division of household work within couples is in line with gender specific preferences. However, the importance of gender identity and the social cost of breaking norms should probably not be underestimated in this context.

Matching of couples is crucial for the effect of parenthood on labor market outcomes. However, we do not know how the matching works; what are the important determinants? This is of course unobservable information, but we know that women are the ones who carry the child for almost one year and women are also the ones who breast feed. We also know that the age gap between couples is about 2 years. These facts may be related to each other. Women face a larger initial cost of entering parenthood (due to pregnancy and breast feeding) and they may therefore demand a larger insurance coverage, than is the case for men. The partner's income can serve as a within-family insurance coverage. A higher age often imply a more stable income, thus, this insurance demand among women could, theoretically, explain why women demand an older partner. However, a puzzling fact against this explanation is that despite a large increase in social protection during the last century, the age gap between couples in Denmark, with a very similar progress of social protection as in Sweden, has remained constant (Drefahl, 2010) for the same period. Based on this observation it thus seems that the way couples match matching is difficult to affect by public policy.

Finally, it is important to note that our results do not suggest that 
women bear the total cost of children. The conclusion is that women give up more effort on the labor market in order to invest more effort in rearing children in comparison to men. If income is shared within the household and labor market work generates less utility than spending time with the children, fathers may actually be the losers, since time with children cannot be shared in the same way as income.

\section{References}

Albrecht, J. W. Edin, P.A., Sundström, M. Vroman, S. B. (1999). "Career Interruptions and Subsequent Earnings: A Reexamination Using Swedish Data", The Journal of Human Resources, Vol. 34, No. 2 (Spring, 1999), pp. 294-311.

Akerlof, G.A. och Kranton, R.E. (2000). "Economics and Identity", Quarterly Journal of Economics, CXV (3), August, pp. 715-753.

Angrist, J. and Evans, W. (1998). "Children and their parents' labor supply: evidence from exogenous variation in family size", American Economic Review 88 (3): 450-477.

Azmat, Ghazala and Ferrer, Rosa (2012) "Gender Gaps in Performance: Evidence from Young Lawyers ", Barcelona GSE Working Paper Series, Working Paper nr 604

Becker, G. (1985) "Human Capital, Effort, and the Sexual Division of Labor)" Journal of Labor Economics, Vol. 3, No. 1, Part 2: Trends in Women's Work, Education, and Family Building (Jan., 1985), pp. S33S58.

Blau, F. (1998) "Trends in the Well-Being of American Women 19701995." Journal of Economic Literature 36(1):112-65.

Blau, F. and Kahn, L. (1997) "Swimming Upstream: Trends in the Gender Wage Differential in the 1980s". Journal of Labor Economics 15(1):1-42.

Blau, F. and Kahn, L. (2000) "Gender differences in pay", Journal of 
Economic perspectives, 14(4), 75-99.

Booth, A.L. and Van Ours, J.C. (2005) "Hours of work and gender identity: Does part-time work make the family happier?", CEPR Discussion Paper No 5438, London.

Boschini, A., Håkansson, C., Rosén, Å. and Sjögren, A. (2011) "Trading off or having it all ? - Completed fertility and mid-career earnings of Swedish men and women", Working paper 2011:15, IFAU.

Boye, K. (2008) Happy hour? Studies on well-being and time spent on paid and unpaid work, Swedish Institute for Social Research Dissertation Series no. 74 .

Blundell, R., Chiappori, P.-A., and C. Meghir (2005), "Collective labor supply with children", Journal of Political Economy vol. 113(6), 12771306.

Bronars, S. G. and Grogger, J. (1994), "The economic consequences of unwed motherhood: Using twin births as a natural experiment", American Economic Review 84(5), 1141-56.

Browning, M., Chiappori, P.-A., and Y. Weiss (2011) Family Economics, book draft, January 2011, available at

http://www.cemmap.ac.uk/resources/chiappori/paper_1.pdf

Budig, M., and England, P. (2001) "The wage penalty for motherhood" American Sociology Review. Vol. 66, No. 2, pp. 204-225.

Cherchye, L., De Rock, B., and F. Vermeulen (2012), "Married with children: a collective labor supply model with detailed time use and intrahousehold expenditure information ", American Economic Review, vol. 102(7), pp. $3377-3405$.

Chiappori, P. A., (1991) "Nash-Bargained Household Decisions: A Rejoinder", International Economic Review, vol. 32(3), pages 761-62, August.

Datta Gupta, N. and Smith, N. (2002) "Children and Career Interruptions: 
The Family Gap in Denmark", Economica, New Series, Vol. 69, No. 276 (Nov., 2002), pp. 609-629.

Drefahl, S. (2010) "How Does the Age Gap Between Partners Affect Their Survival?" Demography, Volume 47, Number 2, May 2010, pp. 313-326

Edin, P. and Richardsson, K. (2002) "Swimming with the tide: solidarity wage policy and the gender earnings gap", Scandinavian Journal of Economics, 104 (2002): 49-67.

Engström, P. Kolm, A-S., and Che-Yuan Liang (2009) "Maternal-biased parental leave", Journal of Economic Psychology 30, 2009.

Evertsson, M. and Nermo, M. (2007). "Changing resources and the division of housework: A longitudinal study of Swedish couples", European Sociological Review, 23, 455-470.

Försäkringskassan (2011) Socialförsäkringen i siffror 2011 (in Swedish).

Fredriksson, P. and Johansson, P. (2008). "Dynamic treatment assignmentThe consequences for evaluations using observational data", Journal of Business and Economic and Statistics.

Gauthier, A. and Furstenberg, F.F. Jr. (2002) "The transition to adulthood: a time use perspective", The Annals of the American Academy of Political and Social Science, March:153-171

Goldin, C. (1990) Understanding the Gender Gap New York: Oxford University Press.

Heckman, J. (1978) "A partial survey of recent research on the labor supply of women", American Economic Review, 68 (Supplement), pp. 200-207.

Hotz VJ, McElroy SW, Sanders SG (2005) "Teenage childbearing and its life cycle consequences: exploiting a natural experiment" Journal of Human Resources 60(3), pp. 683-715

Kennerberg, L. (2007) "Hur förändras kvinnors och mäns arbetssituation när de får barn?" IFAU-rapport 2007:9. Institutet för arbetsmarknads- och 
utbildningspolitisk utvärdering, Uppsala (in Swedish).

Klepinger D, Lundberg S, Plotnick R (1999) "How does adolescent fertility affect the human capital and wages of young women?" Journal of Human Resources 34(3), pp. 421-448

Konrad, K. A. and Lommerud, K. E. (1995) "Family policy with noncooperative families", Scandinavian Journal of Economics, 97, 581-601.

Loughren, D. and Zissimopolus, J. (2008) "Why Wait? The Effect of Marriage and Childbearing on the Wages of Men and Women", WR-482-1. RAND, Santa Monica, CA 90407.

Manser, M. and Brown, M. (1980) "Marriage and Household DecisionMaking: A Bargaining Analysis", International Economic Review, vol. 21(1), pp. 31-44, February.

McElroy, M. and Horney, M. (1981) "Nash-Bargained Decisions: Toward a Generalization of the Theory of Demand", International Economic Review, 22, pp. 333-349.

Miller A. R. (2011) "The effects of motherhood timing on career path", Journal of Population Economics 24, pp. 1071-1100

Mincer J. (1966) "Labor Force Participation of Married Women: A Study of Labor Supply", in Aspects of Labor Economics. Princeton, N.J.: Princeton University Press, 1966.

O’Neill, J. and Polachek, S., (1993) "Why the Gender Gap in Wages Narrowed in the 1980s", Journal of Labor Economics 11(1):205-28.

Phipps, S. A., and P. S. Burton (1998): "What's Mine Is Yours? The Influence of Male and Female Incomes on Patterns of Household Expenditure", Economica, 65(260), 599-613.

Pollak, R. A. (2005): Bargaining Power in Marriage: Earnings, Wage Rates and Household Production, Washington University in St. Louis.

Sasser, A. (2005) "Gender Differences in Physician Pay: Tradeoffs between 
Career and Family", The Journal of Human Resources, Vol. 40, No. 2 (Spring, 2005), pp. 477-504

SCB (2009) "Inkomstskillnaderna mellan könen har ökat", Välfärd, vol. 1 (in Swedish).

Selin, H. (2009) "The Rise in Female Employment and the Role of Tax Incentives. An Empirical Analysis of the Swedish Individual Tax Reform of 1971", UCFS Working Paper 2009:3.

Thomas, D. (1990): "Intra-Household Resource Allocation: An Inferential Approach ", The Journal of Human Resources, 25(4), 635-664.

Thomas, D. (1994): "Like Father, Like Son: Like Mother, Like Daughter: Parental Resources and Child Height", The Journal of Human Resources, 29(4), 950-988.

Tichenor, V. (1999) "Status and income as gendered resources: The case of marital power", Journal of Marriage and the Family, 61, 638-650.

Van der Lippe, T. and Siegers, J. (1994) "Division of Household and Paid Labour between Partners: Effects of Relative Wage Rates and Social Norms", Kyklos, 47: 109-136.

Waldfogel, J. (1997) "The Effect of Children on Women's Wages", American Sociological Review, 62, 209-217.

West, C. and Fenstermaker, S. (1995) "Doing Difference", Gender and Society, 9(1)8-37.

White, Halbert (1980), "A Heteroskedasticity-Consistent Covariance Matrix Estimator and a Direct Test for Heteroskedasticity ", Econometrica 48 (4): $817-838$

Wood, R., Corcoran, M. and Courant, P. (1993) "Pay Differences Among the Highly Paid: Male-Female Earnings gap in Law Salaries", Journal of Labor Economics 11(3):417-44. 


\section{Appendix A: Empirical strategy}

Let $\left\{Y_{j t}(1)\right\}_{t=1}^{T}, j=f, m$, be the potential income stream after becoming a parent for the females and males, in time period $t=0$, and let $\left\{Y_{j t}(0)\right\}_{t=1}^{T}, j=f, m$, be the corresponding income stream if not becoming a parent. Furthermore, let $\left\{y_{j t}\right\}_{t=-L}^{T}, j=f, m$, be the observed income stream since labor market entry which occurs $L$ years before receiving the first child. The average expectations that couples have at $t=0$ regarding their within-couple income differences at time period $t>0$, for couples that became parents at $t=0$ are defined as

$$
\alpha_{t}=\mathrm{EE}_{t=0}\left\{\widetilde{Z}_{t} \mid \text { parent }=\text { yes }\right\}
$$

where $\widetilde{Z}_{t}=\left(Y_{m t}(1)-Y_{f t}(1)\right)-\left(Y_{m t}(0)-Y_{f t}(0)\right)$.

The gender difference in potential outcomes after having a child is thus by definition equal to

$$
\left(Y_{m t}(1)-Y_{f t}(1)\right)=\left(Y_{m t}(0)-Y_{f t}(0)\right)+\widetilde{Z}_{t}, t>0
$$

Assume that either (i) the income difference in the absence of a child would be constant,

$$
\left(Y_{m t}(0)-Y_{f t}(0)\right)=\delta+\varepsilon_{t}, t>0
$$

or that it is a unit-root process (ii)

$$
\left(Y_{m t}(0)-Y_{f t}(0)\right)=\left(Y_{m t-1}(0)-Y_{f t-1}(0)\right)+\varepsilon_{t}, t>0
$$

where $\varepsilon_{t}$ is a random noise. Substitute for $\left(Y_{m t}(1)-Y_{f t}(1)\right)$ and $\left(Y_{m-1}(0)-Y_{f-1}(0)\right)$ with the observed outcomes $\left(y_{m t}-y_{f t}\right)$ and $\left(y_{m-1}-y_{f-1}\right)$ and by making use of (i) we get

$$
\left(y_{m t}-y_{f t}\right)=\delta+\widetilde{Z}_{t}+\varepsilon_{t}, t>0
$$

while using (ii) results in

$$
\left(y_{m t}-y_{f t}\right)=\left(y_{m-1}-y_{f-1}\right)+\widetilde{Z}_{t}+\sum_{j=-1}^{t} \varepsilon_{j}, t>0 .
$$

Let $i=1, \ldots, n$, index $n$ household then a consistent estimator of the 
estimand (4) is given as (i)

$$
\begin{aligned}
\widehat{\alpha}_{t} & =\frac{1}{n} \sum_{i=1}^{n}\left\{y_{i m t}-y_{i f t}-\left(y_{i m-1}-y_{i f-1}\right)\right\} \\
& =\frac{1}{n} \sum_{i=1}^{n} \widetilde{Z}_{i t}+\frac{1}{n} \sum_{i=1}^{n} \varepsilon_{i t} .
\end{aligned}
$$

or (ii)

$$
\begin{aligned}
\widehat{\alpha}_{t} & =\frac{1}{n} \sum_{i=1}^{n}\left\{y_{i m t}-y_{i f t}-\left(y_{i m-1}-y_{i f-1}\right)\right\} \\
& =\frac{1}{n} \sum_{i=1}^{n} \widetilde{Z}_{i t}+\frac{1}{n} \sum_{i=1}^{n} \sum_{j=-1}^{t} \varepsilon_{i j} .
\end{aligned}
$$

Under the assumption $\varepsilon_{i t}, \forall t>0$, are not used in the decision making of parenthood in the household (i.e. $\varepsilon_{i t}$ are strictly exogenous) then we get

$$
\operatorname{plim} \widehat{\alpha}_{t}=\alpha_{t}, t>0
$$

To summarize, we are able to consistently estimate the parameters of interest (4) for $t>0$ either under the assumption of a constant counterfactual gender income difference, or of a unit-root process.

It can be convenient to estimate $\alpha_{t}$ by taking use of ordinary least squares (OLS) as it allow for control for calendar time effects and/or for potential confounder. Under the above assumptions we get:

$$
\left(y_{i m t}-y_{i f t}\right)=\delta_{i}+\sum_{j=0}^{T} \alpha_{i j} \mathbf{1}_{t=j}+u_{i t}, t \geq 0,
$$

where $\delta_{i}=\left(y_{i m-1}-y_{i f-1}\right)$ and $u_{i t}$ is either $\varepsilon_{i t}$ or $\sum_{j=-1}^{t} \varepsilon_{i j}$. Here we have made the heterogeneity of treatment effects explicit by specifying $\alpha_{i j}=$ $\alpha_{j}+\eta_{i j}$, where hence $\eta_{i j}$ measure the deviation from the mean effect of parenthood. Then

$$
\left(y_{i m t}-y_{i f t}\right)=\delta_{i}+\sum_{j=0}^{T} \alpha_{j} \mathbf{1}_{t=j}+\sum_{j=0}^{T} \eta_{i j} \mathbf{1}_{t=j}+u_{i t}, t \geq 0
$$


The crux in estimating (9) with OLS is that $\eta_{i j}$ most likely is correlated with $\delta_{i}$. Couples where women have high cost (i.e. $\eta_{i j}$ is low) may be the same couples where the pre birth earnings differential are large (i.e., $\delta_{i}$ is low). Neglecting to take this into account the OLS estimator of $\alpha_{j}$ will biased estimator. However $\delta_{i}$ is easily removed by simply differentiating (9) hence

$$
\left(y_{i m t}-y_{i f t}\right)-\left(y_{i m-1}-y_{i f-1}\right)=\sum_{j=0}^{T} \alpha_{j} \mathbf{1}_{t=j}+\sum_{j=0}^{T} \eta_{i j} \mathbf{1}_{t=j}+u_{i t}, t \geq 0 .
$$

This model can then be estimated with OLS. 


\section{Appendix B: Figures}
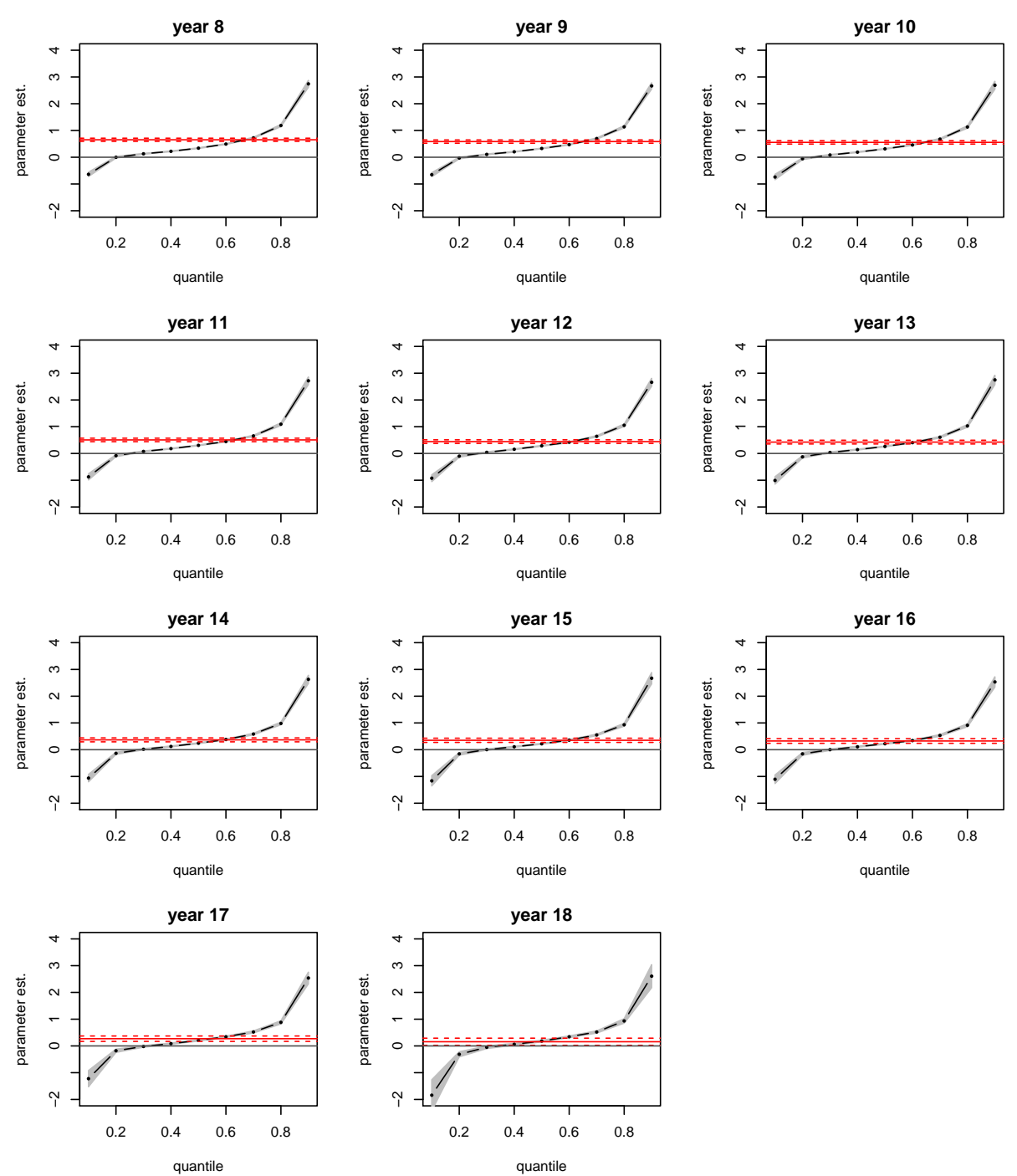

Figure 7: The effect of family formation on the change in the within-couple income gap: years 8 through 18 .

Note: The effect is measured in various parts of the conditional distribution of the outcome variable $\left(\ln y_{i m t}-\ln y_{i f t}\right)-\left(\ln y_{i m-2}-\ln y_{i f-2}\right), t \geq-1$ with $y_{\text {imt } / \text { ift }}$ being the yearly income of the male/female within each couple in year $t$. We use quantile regressions with the following control variables: calendar year dummies; within-couple age gap; and pre-child within-couple differences in education. The dashed curve with dots represents quantile-regression estimates for different quantiles on the X-axis, with corresponding 95\% CI (shaded area). For reference, the OLS-estimate with the same controls is included (straight line with the corresponding dashed 95\% CI). The various graphs represent parameter estimates of the yearly effect of having a child, measured as the percentage change in the gender gap in comparison to the the pre-birth gap. 

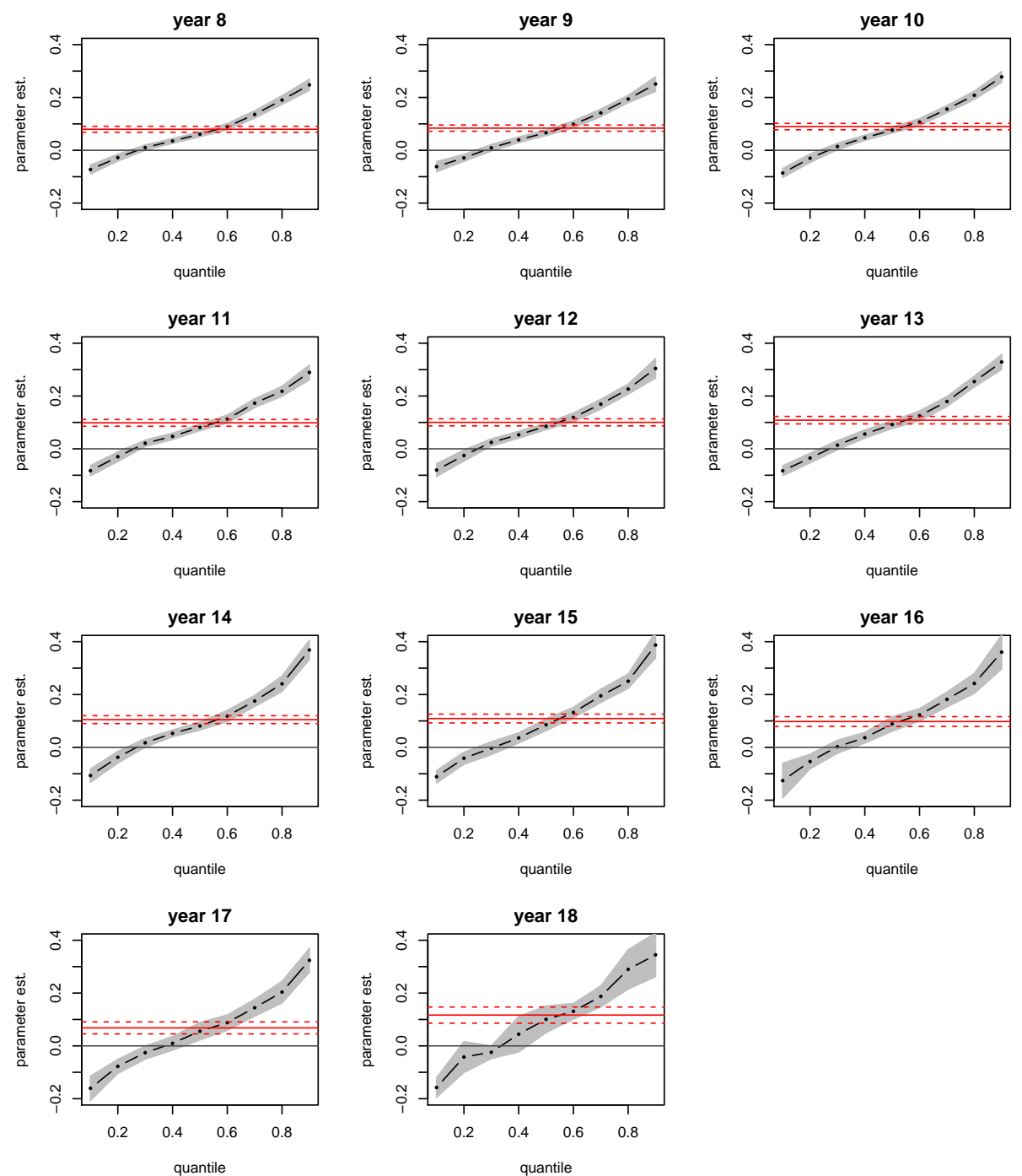

Figure 8: The effect of family formation on the change in the within-couple wage gap: years 8 through 18 .

Note: The effect is measured in various parts of the conditional distribution of the outcome variable $\left(\ln y_{i m t}-\ln y_{i f t}\right)-\left(\ln y_{i m-2}-\ln y_{i f-2}\right), t \geq-1$ with $y_{i m t / i f t}$ being the monthly wage of the male/female within each couple in year $t$. We use quantile regressions with the following control variables: calendar year dummies; within-couple age gap; and pre-child within-couple differences in education. The dashed curve with dots represents quantile-regression estimates for different quantiles on the X-axis, with corresponding 95\% CI (shaded area). For reference, the OLS-estimate with the same controls is included (straight line with the corresponding dashed 95\% CI). The various graphs represent parameter estimates of the yearly effect of having a child, measured as the percentage change in the gender gap in comparison to the the pre-birth gap. 